\title{
Impact of coronary lesion complexity in percutaneous coronary intervention: 1-year outcomes from the large, multicenter e-ULTIMASTER registry
}

Running title: Long-term outcomes of complex PCI

Mohamed O. Mohamed ${ }^{1}$, MRCP, Jawed Polad ${ }^{2}$, M.D., David Hildick-Smith ${ }^{3}$, M.D., FRCP, Olivier Bizeau ${ }^{4}$, M.D., Ruslan K. Baisebenov ${ }^{5}$, M.D., Marco Roffi ${ }^{6}$, M.D., Andres IñiguezRomo $^{7}$, M.D., Bernard Chevalier ${ }^{8}$, M.D., Clemens von Birgelen ${ }^{9}$, M.D., PhD, Ariel Roguin ${ }^{10}$, MD, PhD, Adel Aminian ${ }^{11}$, M.D., Michael Angioi ${ }^{12}$, M.D., Mamas A. Mamas ${ }^{1}$, DPhil, MRCP on behalf of the e-Ultimaster investigators

1. Keele Cardiovascular Research Group, Centre for Prognosis Research, Institutes of Applied Clinical Science and Primary Care and Health Sciences, Keele University, United Kingdom; 2. Jeroen Bosch Hospital, 's- Hertogenbosch, The Netherlands; 3. Sussex Cardiac Centre, Brighton and Sussex University Hospital, Brighton, UK; 4. Centre hospitalier régional OrléansLa-Source, Orléans, France; 5. Regional Cardiology Center, Pavlodar, Kazakhstan; 6. Geneva University Hospitals, Geneva, Switzerland; 7. Hospital Álvaro Cunqueiro - Vigo, Spain; 8. Ramsay Générale de Santé, Institut Cardiovasculaire Paris Sud, Massy, France; 9. Twente, Medisch Spectrum Twente, Enschede, Netherlands; 10. Hillel Yaffe Medical Center, Hadera, Israel; 11. Centre Hospitalier Universitaire Charleroi, Charleroi, Belgium; 12. Clinique Pasteur, Essey-les-Nancy, France.

\section{Correspondence to:}

Mamas A. Mamas

Professor of Cardiology

Keele Cardiovascular Research Group,

Centre for Prognosis Research,

Institute for Primary Care and Health Sciences,

Keele University, UK

mamasmamas1@yahoo.co.uk

Word count: 4951

Key Words: Newer generation drug-eluting stent, clinical trials, Ultimaster sirolimuseluting stent; complex PCI; coronary interventions 
Head and shoulder portrait of the first author (300 DPI)

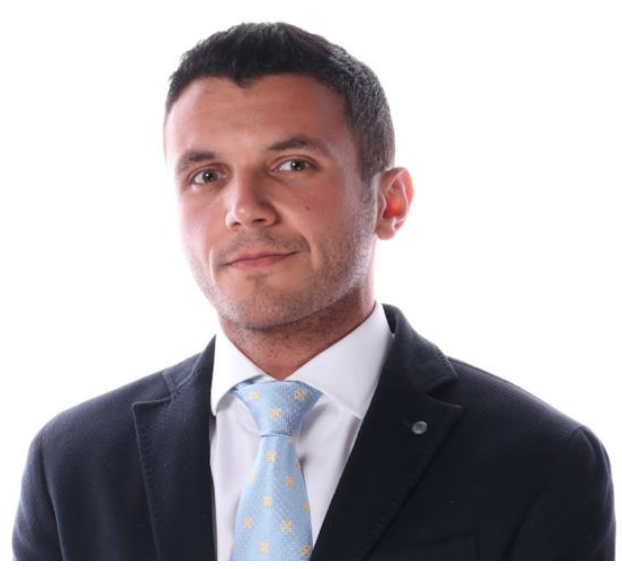

Abbreviations

CTO Chronic total occlusion

DES Drug eluting stent

OR Odds ratio

PCI Percutaneous coronary intervention

POCE Patient oriented composite endpoint

TLF Target lesion failure

TVR Target vessel revascularization 


\section{Abstract (<200 words)}

Aims: The present study sought to examine the prevalence, clinical characteristics and 1-year outcomes of patients undergoing percutaneous coronary intervention (PCI) to complex lesions (multivessel PCI, $\geq 3$ stents, $\geq 3$ lesions, bifurcation with $\geq 2$ stents, total stent length $>60 \mathrm{~mm}$ or chronic total occlusion (CTO)) in a prospective multicentre registry.

Methods and Results: Using the e-Ultimaster multicentre registry, a post-hoc sub-group analysis was performed on 35,839 patients undergoing PCI, stratified by procedure complexity, and further by number and type of complex features. Overall, complex PCI patients $(n=9,793$, $27.3 \%$ ) were older, more comorbid and were associated with an increased hazard ratio (HR) of composite endpoint at 1-year (target lesion failure (TLF): 1.41 [1.25; 1.59]), driven by increased hazard of cardiac death $(1.28[1.05 ; 1.55])$, target vessel myocardial infarction $(1.48$ $[1.18 ; 1.86])$ and clinically driven target lesion revascularisation. The hazard of complications increased with rising number of complex features (3-6 vs. 1-2 vs. none) for all outcomes. All individual complex features were associated with an increased hazard of composite complications (except CTO) and definite/probable stent thrombosis.

Conclusions: Overall, complex PCI is associated with an increased risk of mortality and complications at 1-year. The number and types of complex features have differing impacts on long-term outcomes. 


\section{Condensed Abstract (77 words)}

The present study examined real-world outcomes of complex PCI from the e-Ultimaster multicentre registry, stratified by number and type of complex features. Complex lesions were associated with an increased risk of cardiac death and complications at 1-year as compared to non-complex PCI patients. Prognostic differences were observed between individual complex lesions, with the worst outcomes observed among patients with bifurcations with 2 stents whereas no difference was observed in outcomes other than stent thrombosis in CTO patients.

\section{Introduction}

Advances in procedural and imaging techniques, stent platforms and operator experience have led to an increase in PCI in patients with complex coronary lesions. ${ }^{3-5}$ Complex PCI is often used to describe interventions on lesions with challenging anatomical characteristics, including left main involvement, heavily calcified lesions, heavily thrombotic lesions, chronic total occlusions (CTO), bifurcation lesions or multivessel disease. ${ }^{4}{ }^{6}$ Several high-risk features for stent-related recurrent ischemic events have been described in the 2017 European Society of Cardiology (ESC) update on dual antiplatelet therapy (DAPT), including prior stent thrombosis despite adequate antiplatelet therapy, stenting of the last remaining patent coronary artery, diffuse multivessel disease, chronic kidney disease (CKD), $\geq 3$ stents implanted, $\geq 3$ lesions treated, bifurcation lesions treated with 2 stents, total stent length $>60$ mm, and treatment of CTO. ${ }^{1,6}$

Previous studies examining outcomes of complex, high risk lesions have either analysed all complex lesions collectively or only focused on specific lesion types (e.g. CTO or bifurcation disease). ${ }^{6-11}$ Furthermore, many studies were performed on highly selected cohorts, included stent platforms that are not commonly used such as bare metal stents (BMS) or early generation drug eluting stents (DES). ${ }^{12} 6$ Furthermore, differences in stent platforms used for particular lesion subsets, may confound comparative outcomes reported amongst different 
complex lesion subtypes. ${ }^{6,13}$ There is limited data on the prevalence and clinical outcomes of complex lesions in the real-world, and whether the clinical outcomes from individual complex features vary either by type or by number.

The present study sought to examine the effect of lesion complexity on 1-year clinical outcomes in a large and unselected cohort of PCI procedures from the e-Ultimaster multicentre registry, stratified by number and type of complex PCI features.

\section{Methods}

\section{Study design and patient population}

The e-ULTIMASTER is a prospective, multicentre, observational registry with a primary objective to further evaluate the safety and performance of the Ultimaster DES system (Terumo Corporation, Tokyo, Japan) in an all-comer patient population. There were no further inclusion or exclusion criteria in order to enrol an unselected patient cohort. The selection process for our study cohort is illustrated in Supplementary Figure S1. For this post-hoc subgroup analysis, complex PCI patients were identified based upon the presence of one or more of the following characteristics in the index procedure: multivessel PCI, $\geq 3$ stents implanted,

$\geq 3$ lesions treated, bifurcation PCI with $\geq 2$ stents, total stent length $>60 \mathrm{~mm}$ or chronic total occlusion (CTO). The complex procedural characteristics defined in our study were those described in 2017 ESC guidelines on DAPT, based on the pooled patient-level meta-analysis by Giustino et al. ${ }^{6}{ }^{1}$ Further information on trial registration, study device and follow up is available in Appendix A. A full list of participating centres is presented in Appendix B.

\section{Outcomes and definitions}

The primary outcome is target lesion failure (TLF) defined as a composite of cardiac death, myocardial infarction that could not be clearly attributed to a vessel other than the target vessel (target vessel MI) and clinically driven target lesion revascularization (CD-TLR) at 1year. All primary outcome related adverse events were adjudicated by an independent clinical 
events committee. Sub-categories of death (cardiac death, vascular death and noncardiovascular) were adjudicated according the Academic Research Consortium (ARC) definitions. ${ }^{14}$ For myocardial infarction, the extended historical myocardial definition was applied that primarily uses creatine kinase $\mathrm{MB}$ as cardiac biomarker criterium, but if not measured, troponin values for the determination of a peri-procedural ( $<48$ hours post PCI), reinfarction ( $<48$ hours post PCI) or spontaneous MI $\left(>48\right.$ hours post PCI). ${ }^{15}$ Revascularizations and stent thrombosis were based upon the ARC definitions. ${ }^{14}$ Bleeding was defined according to the Bleeding Academic Research Consortium (BARC) definitions. ${ }^{16}$ Target vessel failure (TVF) was defined as a composite of cardiac death, target vessel MI and TVR; patient-oriented composite endpoint (POCE) as the composite of any death, any MI and any coronary revascularization).

\section{Follow up}

Follow-up was either performed by a direct phone contact with the patient or visit of the patient to the outpatient clinic of the hospital. Collection of adverse events was done through a web-based database. At each follow-up, there was a specific question whether any adverse event occurred. If answered positively, all events had to be reported, i.e. death, myocardial infarction, re-PCI, CABG, bleeding, vascular complication, stent thrombosis or other. Further relevant information was collected per event type.

\section{Statistical analysis}

Complex PCI patients were compared to patients without any of the complex features (non-complex patients). The complex patient subgroup was further divided into patients with 1-2 complex features and 3-6 complex features. Patients demographics, comorbidities, medical history, target lesion characteristics and procedural characteristics are summarized with mean \pm standard deviation for continuous variables and with frequencies and percentages for 
categorical variables. The Chi-square test was used to compare categorical variables and the ttest to compare continuous variables. For non-normal distributed data, nonparametric tests (i.e. Kruskal-Wallis Test) have been used, as appropriate. The Kaplan-Meier method was used to construct survival curves for time-to-event variables, which were compared by means of the log-rank test. Cox proportional hazard ratios (HRs) were calculated for all complex sub-groups (overall complex, 1-2 and 3-6 components, and each individual component) using the nocomplex group as the reference category, adjusting for the following factors: age, sex, diabetes, hypertension, hypercholesterolaemia, smoking history, renal impairment, clinical presentation (acute coronary syndrome (ACS) vs. chronic coronary syndrome) and a previous history of the myocardial infarction (MI), percutaneous transluminal coronary angioplasty (PTCA) or coronary artery bypass grafting $(\mathrm{CABG})$. A two-sided $\mathrm{P}$ value $<0.05$ was considered to indicate statistical significance. Statistical analyses were performed using SAS software, version 9.4 (SAS Institute, Inc., Cary, NC, USA).

\section{Results}

Out of 37,261 patients recruited in the e-Ultimaster study, a total of 35,839 patients with 1-year follow up data were included in the final analysis, of whom 9,793 (27.3\%) underwent complex PCI. Within the complex PCI group, the majority of patients had 1-2 complex PCI features $(73.3 \%, n=7174)$ whereas only $26.7 \%(n=2619)$ had 3-6 complex features. The distribution of different complex PCI features is illustrated in Figure 1. The most prevalent features were multivessel PCI (16.3\%) followed by $\geq 3$ stents implanted (12.3\%) and $\geq 60 \mathrm{~mm}$ stent length $(8.8 \%)$.

\section{Patient characteristics}

Several key differences in patient characteristics are observed between complex and non-complex PCI groups, all at a p-value <0.0001 unless otherwise stated (Table 1). In 
comparison to the non-complex PCI group, patients undergoing complex PCI were older (64.9 \pm 11.1 vs. $63.9 \pm 11.3$ years), more often males $(78.4 \%$ vs. $75.1 \%)$, and had a higher prevalence of diabetes mellitus (32.1\% vs. 27.0\%), hypercholesterolaemia (61.7\% vs. $59.2 \%)$, hypertension (70.3\% vs. $66.8 \%)$ and renal impairment (8.2\% vs. 6.6\%). Previous MI (26.0\% vs. $21.6 \%$ ) and coronary revascularization (PCI: $28.1 \%$ vs. $25.2 \%$; CABG: $6.7 \%$ vs. $5.2 \%$ ) were more frequent in the complex PCI group. The indication for the PCI was more commonly chronic coronary syndrome in the complex PCI group $(52.8 \%$ vs. $41.8 \%)$. The observed differences in patient characteristics were more pronounced as the number of complex PCI factors increased (Supplementary Table 1).

\section{Procedural characteristics}

Procedural characteristics differed between the two groups; all p-values $<0.0001$. There was a lower rate of utilization of radial access in complex compared to non-complex PCI procedures (76.7\% vs. $84.3 \%$ ) (Supplementary Table 2). The majority of PCI procedures were performed on the LAD, more so in the complex PCI group (63.5\% vs. $47.0 \%)$. Overall, there were higher rates of intervention for in-stent restenosis lesions (7.5\% vs. $4.5 \%)$ as well as bifurcation (20.3\% vs. $8.6 \%$ ) and ACC/AHA type B2/C lesions (47.2\% vs. $39.3 \%)$ in the complex PCI group. Complex PCI lesions required longer stents on average, both per patient $(48.3 \pm 26.7 \mathrm{~mm}$ vs. $24.5 \pm 10.3 \mathrm{~mm})$ and per lesion $(30.0 \pm 18.3 \mathrm{~mm}$ vs. $23.3 \pm 9.6 \mathrm{~mm})$. The differences in lesion characteristics between complex and non-complex PCI groups were more pronounced with increasing number of complex factors (3-6 factors $>1-2$ factors $>$ none), Supplementary Table 3). Adherence to DAPT and lipid lowering therapy (including stating) was higher in the complex PCI than non-complex PCI group (DAPT: 70.3\% 65.8\%; lipid lowering therapy: $78.8 \%$ vs. $74.1 \%, \mathrm{p}<0.0001$ for both, Supplementary Table 2), and increased in proportion to the number of complex features (3-6 features $>1-2$ features $>$ none: 
DAPT: $71.3 \%$ vs. $70.0 \%$ vs. $65.8 \%$; lipid lowering therapy: $80.1 \%$ vs. $78.4 \%$ vs. $74.1 \%$, $\mathrm{p}<0.0001$ for both, Supplementary Table 3).

30-day and 1-year outcomes

The rates of composite endpoints (TLF, TVF and POCE) were all significantly higher in complex PCI than non-complex PCI groups, both at 30 days (TLF and TVF $1.4 \%$ vs. $0.8 \%$ each; POCE: $1.9 \%$ vs. $1.1 \%$, p<0.0001 for all) and at 1 year (TLF: $4.2 \%$ vs. $2.8 \%$; TVF: $4.8 \%$ vs. 3.3\%; POCE: $7.9 \%$ vs. $6.0 \%$, p<0.0001 for all). (Table 2) Similarly, rates of all-cause and cardiac death at 30 days and 1-year were both higher in the complex PCI group, as were the rates of ischemic outcomes. Although there was no difference in all-cause and BARC 3-5 bleeding between complex and no-complex PCI groups at 30 days, both events were higher in the complex group at 1-year (any bleeding: $2.4 \%$ vs. $2.0 \%, \mathrm{p}=0.03$ and major bleeding: $0.8 \%$ vs. $0.5 \%, \mathrm{p}<0.01)$. There was no difference in rates of Q-wave MI and clinically-driven target vessel CABG revascularization between complex and non-complex PCI groups at 30-days and 1-year.

After adjustment for baseline differences, the complex PCI group remained at a significantly increased 1-year hazard of composite endpoints (TLF: HR 1.41 [1.25; 1.59], TVF: HR $1.47[1.27 ; 1.69]$ ), as well as individual outcomes (cardiac death: HR 1.28 [1.05; 1.55], target-vessel MI: 1.48 [1.18; 1.86], clinically-driven TLR: 1.42 [1.20; 1.68]). (Figures 2A-2D, Table 2)

A stepwise increase in 1-year event rate of TLF was observed as the number of complex PCI factors increased, driven by increasing rates of cardiac death (none vs. 1-2 vs. 3-6: 1.2\% vs. $1.5 \%$ vs. $1.8 \%$ ), target vessel MI (none vs. $1-2$ vs. $3-6: 0.8 \%$ vs. $1.1 \%$ vs. $1.6 \%$ ) and clinically driven TLR (none vs. 1-2 vs. 3-6: $1.5 \%$ vs. $2.0 \%$ vs. $2.4 \%$ ). (Supplementary Table 4) Similarly, the rates for the other composite endpoints TVF and POCE increased in line with 
rising number of complex PCI factors. Definite/probable stent thrombosis rates increased from no complex feature to 1-2 complex features and further to 3-6 complex features ( $0.6 \%$ vs. $0.9 \%$ vs. $1.1 \%$, respectively). These findings persisted after adjustment for baseline differences, with an incremental rise in hazard ratio with increasing number of complex features. (Figures 3A3D, Table 3)

A subgroup analysis of 1-year clinical outcomes of individual complex PCI features is summarised in Supplementary Table 5 and further illustrated in Figure 4. Compared to the non-complex PCI group, the rates of composite endpoints (TLF and TVF) were increased with all individual complex features other than CTO, primarily driven by higher incidence of clinically-driven TLR and target vessel MI (except in patients with $\geq 3$ lesions stented). These findings persisted after adjustment for baseline differences, with the greatest hazard observed among bifurcation lesions with 2 stents (TLF: HR 2.01 [1.55; 2.62], and TVF: HR 2.33 [1.73; 3.14], clinically driven TLR: HR 2.31 [1.62; 3.28], target vessel MI: HR 2.53 [1.59; 4.01).

\section{(Table 3, Figure 5)}

\section{Discussion}

This is the largest study to examine the effect of lesion complexity, in terms of both number and type, on one-year outcomes in a large and unselected cohort of more than 35,000 patients undergoing PCI using a single new generation stent platform. Several important conclusions can be drawn from our findings. First, we show that patients with complex lesions undergoing PCI patients are often older, male, with a higher prevalence of traditional cardiovascular risk factors. Second, we find that, overall, complex PCI is associated with worse outcomes at 30-days and 1-year including composite endpoints (TLF, TVF and POCE), allcause and cardiac deaths, any bleeding and BARC 3-5 bleeding, and the majority of ischaemic outcomes. Further, we demonstrate an incremental relationship between the number of complex features and adversity of clinical outcomes including composite adverse outcomes of 
TLF, TVF and POCE as well as secondary outcomes, even in a cohort managed with latest generation DES, emphasising the impact of lesion and procedure complexity on clinical outcomes. Finally, we highlight differences (or lack thereof) in specific outcomes between individual complex PCI features.

\section{Overall procedural complexity}

Although some previous studies have looked at the relationship between lesion complexity and long-term clinical outcomes after PCI, they were subject to the limitations previously described. ${ }^{6,8-11}$ These findings are consistent with those of a recent analysis from the Bern PCI registry that showed an increased (unadjusted) hazard of cardiac death (HR 3.07 [2.43; 3.89]), target vessel MI (HR 1.92 [1.54; 2.39]) and stent thrombosis (HR 1.71 [1.10; 2.65]) in 5323 patients with high-risk PCI features undergoing PCI compared to those without high-risk features. ${ }^{12}$ However, their analysis was based on smaller cohort derived from a single regional centre, and included patients treated with first generation DES and BMS. In a posthoc analysis of randomised controlled trials (RCTs), Giustino et al. reported an increased hazard of cardiac mortality, definite or probable stent thrombosis and TVR, but no difference in stroke or bleeding, between patients undergoing complex and non-complex PCI. ${ }^{6}$ However, their analysis was based on a modest number of complex PCI patients $(n=1680)$, derived from a highly selected cohort from RCTs, and included procedures performed with both early and new generation DES. Although some of these findings were observed in the present study, including higher rates of probable or definite stent thrombosis, myocardial infarction, as well as cardiac death, we show that target lesion and vessel failure, target vessel MI and bleeding (any bleeding and BARC 3-5 bleeding) were also higher in patients with complex PCI. Several factors place complex PCI patients at a heightened risk of further ischemic complications and mortality. Patients undergoing complex PCI are often older, with higher burden of comorbidities and cardiovascular risk factors, as observed in our cohort. Patients undergoing 
complex PCI may also have a greater burden of residual CAD which puts them at a risk of recurrent ischaemic events. Although there is limited literature to explain the higher incidence of major bleeding in complex than no-complex PCI, this is possibly justified by several factors. First, risk factors for ischaemia (hypertension, diabetes, renal failure and advanced age), also increase the risk of bleeding. ${ }^{17}$ Furthermore, complex PCI patients are more likely to receive prolonged DAPT therapy, or more potent P2Y12 agents, which may have contributed to their higher bleeding rates.

\section{Number and types of complex features}

To the best of our knowledge, the present study is the largest to compare an expansive array of 1-year outcomes after complex PCI according to number and type of complex features and informs operators of several important findings. Our analysis shows a positive correlation between the number of complex features (none vs. 1-2 vs. 3-6 features) and all adverse outcomes, primarily driven by higher rates of target vessel MI and clinically driven TLR. Our findings are in keeping with those reported by Ueki et al in their single-centre analysis of 5323 patients with high-risk PCI features, where the number of complex features $(1-2$ and $\geq 3)$ correlated with the adjust hazard of cardiac death, target vessel-MI and definite/probable stent thrombosis. $^{12}$

We also show prognostic differences between individual complex PCI features, with an increased hazard of TLF and TVF among all individual features, driven by increased hazards of clinically-driven TLR and target vessel MI, especially in patients with bifurcation with 2 stents. Another important observation in our analysis is the increased hazard of stent thrombosis with all individual complex features (compared to non-complex PCI). Giustino et al. demonstrated an increased hazard of definite or probable stent thrombosis in specific complex PCI subsets, namely $\geq 3$ stents implanted and bifurcation lesions with 2 stents, whereas 
we found the hazard to be increased with all subsets. ${ }^{6}$ It is possible that their analysis was underpowered to detect differences across all individual groups given their relatively small sample size. The underlying mechanisms behind stent thrombosis are multifactorial and include patient factors (chronic kidney disease, diabetes mellitus, smoking, type of coronary syndrome), type of stent platform and the type and duration of DAPT. ${ }^{18}$

\section{Strengths and Limitations}

Our data was derived from a registry evaluating the efficacy of the Ultimaster stent and enrolled a large number of patients from several regions. Other than the novel findings we report, a strength in our study is that all events composing the primary endpoints were independently adjudicated. However, as with most registries, it is subject to several inherent limitations. First, there is a potential for selection bias and under-reporting of events. In particular, an underestimation of peri-procedural MI cannot be excluded. Peri-procedural biomarker collection, relevant for the detection of usually smaller MI, was per hospital practice and not mandated per-protocol. Measures to ensure data quality included remote and on-site monitoring with a risk-based approach as well a close communication with the sites to reinforce the importance of complete and accurate data entry were adopted. Second, vessel and lesion characteristics were assessed by operators, most commonly through visual estimation, and not measured centrally by a core lab. Third, the outcomes reported are based on the use of a single new-generation stent platform for all patients and these may potentially differ with the use of other new-generation DES. Finally, although we report a follow-up of 1-year, coronary stents are life-long implants and it is possible that further differences between our study groups would be noted on longer follow-up.

\section{Conclusions}

In a real-world cohort of PCI patients, we find that patients with complex target lesions are at an increased risk of cardiac death and complications at 1-year as compared to non- 
complex PCI patients. Even with the use of latest generation DES, we show that a greater number of complex PCI features correlates with higher mortality and worse outcomes. Finally, we demonstrate prognostic differences between individual complex lesions, with the worst outcomes observed among patients with bifurcation treatment using 2 stents, compared to noncomplex PCI patients, and a lack of difference in outcomes other than stent thrombosis in CTO patients. The present findings provide operators with insight regarding the relationship between number and types of lesion complexity and 1-year outcomes after complex PCI.

\section{Impact on daily practice ( 69 words)}

The present study highlights prognostic differences in 1-year outcomes after complex PCI. The findings provide operators with novel insights regarding clinical outcomes of individual complex features and emphasise that the number and type of complex features both have an impact on procedural outcomes. Furthermore, our findings, drawn from a large and contemporary procedural cohort, support those from previous studies examining the overall effect of lesion complexity on PCI outcomes.

\section{Funding}

The e-Ultimaster registry was funded by Terumo Europe, Middle East \& Africa (Leuven, Belgium)

\section{Conflict of interest statement}

Dr Mohamed Mohamed receives funding in support of a PhD scholarship from Medtronic Ltd. Medtronic Ltd. was not involved in the conceptualization, design, conduct, analysis, or interpretation of the current study. Dr von Birgelen reports institutional research grants from Abbott Vascular, Biotronik, Boston Scientific and Medtronic, not related to the present study. Dr Aminian is a consultant for Terumo. 


\section{References}

1. Valgimigli $M$, Bueno $H$, Byrne RA, Collet JP, Costa F, Jeppsson A, Juni P, Kastrati A, Kolh $P$, Mauri L, Montalescot G, Neumann FJ, Petricevic M, Roffi M, Steg PG, Windecker S, Zamorano JL, Levine GN. 2017 ESC focused update on dual antiplatelet therapy in coronary artery disease developed in collaboration with EACTS: The Task Force for dual antiplatelet therapy in coronary artery disease of the European Society of Cardiology (ESC) and of the European Association for Cardio-Thoracic Surgery (EACTS). Eur Heart J 2018;39(3):213-260.

2. Weiss AJ, Elixhauser A. Trends in Operating Room Procedures in U.S. Hospitals, 2001-2011: Statistical Brief \#171. In. Healthcare Cost and Utilization Project (HCUP) Statistical Briefs. Rockville (MD): Agency for Healthcare Research and Quality (US); 2006.

3. Waldo SW, Secemsky EA, O'Brien C, Kennedy KF, Pomerantsev E, Sundt TM, 3rd, McNulty EJ, Scirica BM, Yeh RW. Surgical ineligibility and mortality among patients with unprotected left main or multivessel coronary artery disease undergoing percutaneous coronary intervention. Circulation 2014;130(25):2295-301.

4. Werner N, Nickenig G, Sinning JM. Complex PCl procedures: challenges for the interventional cardiologist. Clin Res Cardiol 2018;107(Suppl 2):64-73.

5. Qian F, Zhong Y, Hannan EL. Relation Between Operator and Hospital Volumes and LongTerm Outcomes for Percutaneous Coronary Intervention in New York. Am J Cardiol 2020;125(5):694711.

6. Giustino G, Chieffo A, Palmerini T, Valgimigli M, Feres F, Abizaid A, Costa RA, Hong MK, Kim BK, Jang Y, Kim HS, Park KW, Gilard M, Morice MC, Sawaya F, Sardella G, Genereux P, Redfors B, Leon MB, Bhatt DL, Stone GW, Colombo A. Efficacy and Safety of Dual Antiplatelet Therapy After Complex PCI. J Am Coll Cardiol 2016;68(17):1851-1864.

7. Brilakis ES, Banerjee S, Karmpaliotis D, Lombardi WL, Tsai TT, Shunk KA, Kennedy KF, Spertus JA, Holmes DR, Grantham JA. Procedural Outcomes of Chronic Total Occlusion

Percutaneous Coronary Intervention: A Report From the NCDR (National Cardiovascular Data Registry). JACC: Cardiovascular Interventions 2015;8(2):245-253.

8. Azzalini L, Carlino M, Bellini B, Marini C, Pazzanese V, Toscano E, Gramegna M, Moscardelli S, Bognoni L, Montorfano M. Long-Term Outcomes of Chronic Total Occlusion Recanalization Versus Percutaneous Coronary Intervention for Complex Non-Occlusive Coronary Artery Disease. Am J Cardiol 2020;125(2):182-188.

9. Wilensky RL, Selzer F, Johnston J, Laskey WK, Klugherz BD, Block P, Cohen H, Detre K, Williams DO. Relation of percutaneous coronary intervention of complex lesions to clinical outcomes (from the NHLBI Dynamic Registry). Am J Cardiol 2002;90(3):216-21.

10. Zhang F, Dong L, Ge J. Simple versus complex stenting strategy for coronary artery bifurcation lesions in the drug-eluting stent era: a meta-analysis of randomised trials. Heart 2009;95(20):1676-81.

11. Brar SS, Gray WA, Dangas G, Leon MB, Aharonian VJ, Brar SK, Moses JW. Bifurcation stenting with drug-eluting stents: a systematic review and meta-analysis of randomised trials.

Eurolntervention 2009;5(4):475-84.

12. Ueki Y, Karagiannis A, Zanchin C, Zanchin T, Stortecky S, Koskinas KC, Siontis GCM, Praz F, Otsuka T, Hunziker L, Heg D, Moschovitis A, Seiler C, Billinger M, Pilgrim T, Valgimigli M, Windecker S, Raber L. Validation of High-Risk Features for Stent-Related Ischemic Events as Endorsed by the 2017 DAPT Guidelines. JACC Cardiovasc Interv 2019;12(9):820-830.

13. Azzalini L, Carlino M, Bellini B, Marini C, Pazzanese V, Toscano E, Gramegna M, Moscardelli S, Bognoni L, Montorfano M. Long-Term Outcomes of Chronic Total Occlusion Recanalization Versus 
Percutaneous Coronary Intervention for Complex Non-Occlusive Coronary Artery Disease. American Journal of Cardiology 2020;125(2):182-188.

14. Cutlip DE, Windecker S, Mehran R, Boam A, Cohen DJ, van Es GA, Steg PG, Morel MA, Mauri L, Vranckx P, McFadden E, Lansky A, Hamon M, Krucoff MW, Serruys PW. Clinical end points in coronary stent trials: a case for standardized definitions. Circulation 2007;115(17):2344-51.

15. Vranckx P, Cutlip DE, Mehran R, Kint PP, Silber S, Windecker S, Serruys PW. Myocardial infarction adjudication in contemporary all-comer stent trials: balancing sensitivity and specificity. Addendum to the historical MI definitions used in stent studies. Eurolntervention 2010;5(7):871-4. 16. Mehran R, Rao SV, Bhatt DL, Gibson CM, Caixeta A, Eikelboom J, Kaul S, Wiviott SD, Menon V, Nikolsky E, Serebruany V, Valgimigli M, Vranckx P, Taggart D, Sabik JF, Cutlip DE, Krucoff MW, Ohman EM, Steg PG, White H. Standardized bleeding definitions for cardiovascular clinical trials: a consensus report from the Bleeding Academic Research Consortium. Circulation 2011;123(23):273647.

17. Mohamed MO, Kinnaird T, Anderson R, Rashid M, Martin GP, Freeman P, Kwok CS, Myint PK, Zaman AG, Mamas MA. Combinations of bleeding and ischemic risk and their association with clinical outcomes in acute coronary syndrome. Int J Cardiol 2019;290:7-14.

18. Kirtane AJ, Stone GW. How to minimize stent thrombosis. Circulation 2011;124(11):1283-7.

\section{Figures legend:}

Figure 1. Prevalence of individual complex PCI components

Legend: CTO: chronic total occlusion; PCI: percutaneous coronary intervention

Figure 2: KM curves for A) TLF, B) Cardiac death, C) Target vessel MI and D) CD TLR for complex and no complex PCI groups

Legend: CD-TLR: clinically driven target lesion revascularisation; MI: myocardial infarction; TLF: target lesion failure

Figure 3: KM curves for A) TLF, B) Cardiac death, C) Target vessel MI and D) CD TLR according to number of complex PCI features

Legend: CD-TLR: clinically driven target lesion revascularisation; MI: myocardial infarction; TLF: target lesion failure

Figure 4. Crude rates of A) TLF, B) Cardiac death, C) Target vessel MI and D) Definite/probable stent thrombosis at 1-year for individual complex risk factors

Legend: TV-MI: target vessel myocardial infarction; TLF: target lesion failure; all p-values refer to comparison with the no-complex PCl group. 
Figure 5. Adjusted hazard ratios (HR) and $95 \%$ confidence intervals (CI) of adverse events*

Legend: *reference is no-complex PCI for each outcome, **definite or probable stent thrombosis

Table 1. Baseline clinical characteristics for population divided into two groups: complex PCI and non-complex PCI

\begin{tabular}{|l|c|c|c|}
\hline & $\begin{array}{c}\text { Complex PCI } \\
(\mathbf{N = 1 0 , 2 4 1})\end{array}$ & $\begin{array}{c}\text { Non-Complex PCI } \\
(\mathbf{N = 2 6 , 9 5 7 )}\end{array}$ & P-value \\
\hline Age (years), mean \pm SD & $64.9 \pm 11.1(10241)$ & $63.9 \pm 11.3(26957)$ & $<0.0001$ \\
\hline Males & $78.4 \%(8024 / 10241)$ & $75.1 \%(20233 / 26957)$ & $<0.0001$ \\
\hline Diabetes mellitus & $32.1 \%(3256 / 10159)$ & $27.0 \%(7123 / 26413)$ & $<0.0001$ \\
\hline Hypertension & $70.3 \%(6652 / 9461)$ & $66.8 \%(16188 / 24223)$ & $<0.0001$ \\
\hline Hypercholesterolemia & $61.7 \%(5631 / 9133)$ & $59.2 \%(13831 / 23346)$ & $<0.0001$ \\
\hline Current smoker & $24.2 \%(2039 / 8443)$ & $27.2 \%(5858 / 21545)$ & $<0.0001$ \\
\hline $\begin{array}{l}\text { Left ventricular ejection } \\
\text { fraction }(\%), \text { mean } \pm \text { SD }\end{array}$ & $52.7 \pm 12.1(4320)$ & $54.1 \pm 11.4(11131)$ & $<0.0001$ \\
\hline Renal impairment* & $8.2 \%(823 / 10089)$ & $6.6 \%(1725 / 26318)$ & $<0.0001$ \\
\hline $\begin{array}{l}\text { Previous myocardial } \\
\text { infarction }\end{array}$ & $26.0 \%(2502 / 9614)$ & $21.6 \%(5350 / 24809)$ & $<0.0001$ \\
\hline Previous PTCA & $28.1 \%(2736 / 9732)$ & $25.2 \%(6290 / 24955)$ & $<0.0001$ \\
\hline Previous CABG & $6.7 \%(647 / 9724)$ & $5.2 \%(1291 / 24838)$ & $<0.0001$ \\
\hline \begin{tabular}{l} 
Clinical presentation \\
\hline $\begin{array}{l}\text { Chronic coronary } \\
\text { syndrome }\end{array}$
\end{tabular} & $52.8 \%(5399 / 10235)$ & $41.8 \%(11273 / 26938)$ & $<0.0001$ \\
\hline $\begin{array}{l}\text { Acute coronary } \\
\text { syndrome }\end{array}$ & $47.2 \%(4836 / 10235)$ & $58.2 \%(15665 / 26938)$ & $<0.0001$ \\
\hline
\end{tabular}

$\mathrm{N}$ : number of patients; CABG: coronary artery bypass graft(ing); LVEF: Left ventricular ejection fraction; PTCA: percutaneous transluminal coronary angioplasty; SD: standard deviation; * renal impartment was defined as a glomerular filtration rate of $<60 \mathrm{~mL} / \mathrm{min} / 1.73 \mathrm{~m}^{2}$ 
Table 2. 30-day and one-year clinical results for according to procedure complexity

\begin{tabular}{|c|c|c|c|c|c|c|}
\hline & \multicolumn{3}{|c|}{ 30-day } & \multicolumn{3}{|c|}{ 1-year } \\
\hline & $\begin{array}{c}\text { Complex PCI } \\
(\mathbf{N}=\mathbf{1 0}, 119)\end{array}$ & $\begin{array}{c}\text { Non-complex } \\
\text { PCI } \\
(\mathbf{N}=\mathbf{2 6 , 4 8 5}) \\
\end{array}$ & p-value & $\begin{array}{c}\text { Complex PCI } \\
(\mathrm{N}=9,793)\end{array}$ & $\begin{array}{c}\text { Non-complex } \\
\text { PCI } \\
(\mathbf{N}=\mathbf{2 5 , 5 9 6 )} \\
\end{array}$ & p-value \\
\hline \multicolumn{7}{|l|}{ Composite endpoints, \% (n) } \\
\hline Target lesion failure & $1.4 \%(137)$ & $0.8 \%(208)$ & $<0.0001$ & $4.2 \%(408)$ & $2.8 \%(727)$ & $<0.0001$ \\
\hline Target vessel failure & $1.4 \%(144)$ & $0.8 \%(221)$ & $<0.0001$ & $4.8 \%(471)$ & $3.3 \%(837)$ & $<0.0001$ \\
\hline $\begin{array}{l}\text { Patient oriented composite } \\
\text { endpoint }\end{array}$ & $1.9 \%(186)$ & $1.1 \%(300)$ & $<0.0001$ & $7.9 \%(774)$ & $6.0 \%(1532)$ & $<0.0001$ \\
\hline \multicolumn{7}{|l|}{ Deaths, $\%(\mathrm{n})$} \\
\hline Any death & $0.8 \%(81)$ & $0.5 \%(127)$ & $<0.001$ & $2.6 \%(256)$ & $1.9 \%(490)$ & $<0.0001$ \\
\hline Cardiac death & $0.7 \%(66)$ & $0.4 \%(97)$ & $<0.001$ & $1.6 \%(157)$ & $1.2 \%(298)$ & 0.001 \\
\hline \multicolumn{7}{|l|}{$\begin{array}{l}\text { Myocardial infarction, \% } \\
\text { (n)* }\end{array}$} \\
\hline Any myocardial infarction & $0.8 \%(83)$ & $0.4 \%(100)$ & $<0.0001$ & $1.5 \%(151)$ & $1.1 \%(272)$ & $<0.001$ \\
\hline $\begin{array}{l}\text { Target vessel myocardial } \\
\text { infarction }\end{array}$ & $0.7 \%(73)$ & $0.3 \%(87)$ & $<0.0001$ & $1.2 \%(117)$ & $0.8 \%(199)$ & $<0.001$ \\
\hline $\begin{array}{l}\text { Target vessel Q Wave } \\
\text { myocardial infarction }\end{array}$ & $0.2 \%(16)$ & $0.1 \%(30)$ & 0.28 & $0.2 \%(22)$ & $0.2 \%(52)$ & 0.69 \\
\hline $\begin{array}{l}\text { Target vessel non Q Wave } \\
\text { myocardial infarction }\end{array}$ & $0.6 \%(57)$ & $0.2 \%(57)$ & $<0.0001$ & $1.0 \%(95)$ & $0.6 \%(147)$ & $<0.0001$ \\
\hline $\begin{array}{l}\text { Non target vessel } \\
\text { myocardial infarction }\end{array}$ & $0.1 \%(10)$ & $0.0 \%$ & 0.09 & $0.4 \%(35)$ & $0.3 \%(77)$ & 0.40 \\
\hline \multicolumn{7}{|l|}{$\begin{array}{l}\text { Clinically-driven target } \\
\text { lesion revascularisations, \% } \\
\text { (n) }\end{array}$} \\
\hline All & $0.4 \%(42)$ & $0.3 \%(84)$ & 0.15 & $2.1 \%(210)$ & $1.5 \%(381)$ & $<0.0001$ \\
\hline
\end{tabular}




\begin{tabular}{|l|c|c|c|c|c|c|}
\hline PCI & $0.4 \%(42)$ & $0.3 \%(79)$ & 0.08 & $2.0 \%(192)$ & $1.4 \%(350)$ & $<0.0001$ \\
\hline CABG & $0.0 \%(0)$ & $0.0 \%(6)$ & 0.13 & $0.2 \%(23)$ & $0.1 \%(35)$ & 0.04 \\
\hline $\begin{array}{l}\text { Clinically-driven target } \\
\text { vessel revascularisations, } \\
(\mathrm{n})\end{array}$ & & & & & & \\
\hline All & $0.5 \%(55)$ & $0.4 \%(102)$ & 0.04 & $2.9 \%(285)$ & $2.0 \%(515)$ & $<0.0001$ \\
\hline PCI & $0.5 \%(55)$ & $0.4 \%(93)$ & 0.01 & $2.7 \%(260)$ & $1.8 \%(464)$ & $<0.0001$ \\
\hline CABG & $0.0 \%(0)$ & $0.0 \%(11)$ & 0.04 & $0.3 \%(31)$ & $0.2 \%(60)$ & 0.17 \\
\hline Stent thrombosis, \% (n) & & & & & & \\
\hline Definite & $0.3 \%(31)$ & $0.2 \%(58)$ & 0.13 & $0.5 \%(49)$ & $0.4 \%(97)$ & 0.11 \\
\hline Probable & $0.3 \%(34)$ & $0.2 \%(48)$ & 0.01 & $0.4 \%(41)$ & $0.2 \%(53)$ & $<0.001$ \\
\hline Definite and probable & $0.6 \%(65)$ & $0.4 \%(104)$ & $<0.01$ & $0.9 \%(90)$ & $0.6 \%(148)$ & $<0.001$ \\
\hline Bleeding, \% (n) & & & & & & \\
\hline Any bleeding & $0.9 \%(86)$ & $0.7 \%(174)$ & 0.05 & $2.4 \%(232)$ & $2.0 \%(511)$ & 0.03 \\
\hline BARC 3-5 & $0.3 \%(26)$ & $0.2 \%(46)$ & 0.11 & $0.8 \%(76)$ & $0.5 \%(126)$ & $<0.01$ \\
\hline
\end{tabular}

*in some cases patients experienced a target vessel as well as a non-target vessel MI at 1-year ( $\mathrm{n}=4$ for non-complex group, $\mathrm{n}=1$ for complex group); Target lesion failure: composite of cardiac death, myocardial infarction that could not be clearly attributed to a vessel other that the target vessel and clinically driven target lesion revascularisation. Target vessel failure: composite of cardiac death, target vessel MI and TVR; Patient-oriented composite endpoint: composite of any death, any MI and any coronary revascularisation; BARC: Bleeding academic research consortium 
Table 3. Hazard ratios (HR) and $95 \%$ confidence intervals of one-year outcomes of study groups*

\begin{tabular}{|c|c|c|c|}
\hline & $\begin{array}{c}\text { Complex PCI } * \\
\text { HR }[95 \% \mathrm{CI}]\end{array}$ & $\begin{array}{c}\text { 1-2 and 3-6 complex features* } \\
\qquad \mathrm{HR}[95 \% \mathrm{CI}]\end{array}$ & $\begin{array}{c}\text { Individual lesions* } \\
\text { HR }[95 \% \mathrm{CI}]\end{array}$ \\
\hline TLF & $1.41[1.25 ; 1.59]$ & $\begin{array}{l}\text { 1-2: } 1.31[1.14 ; 1.50] \\
\text { 3-6: } 1.68[1.39 ; 2.03]\end{array}$ & $\begin{array}{l}\text { Multivessel PCI: } 1.44[1.24 ; 1.66] \\
\geq 3 \text { lesions: } 1.48[1.18 ; 1.86] \\
\geq 3 \text { stents: } 1.64[1.42 ; 1.91] \\
\text { Bifurcation with } 2 \text { stents: } 2.01[1.55 ; 2.62] \\
\text { CTO: } 1.16[0.89 ; 1.52] \\
\text { Total stent length } \geq 60 \mathrm{~mm}: 1.60[1.34 ; 1.91]\end{array}$ \\
\hline TVF & $1.47[1.27 ; 1.69]$ & $\begin{array}{l}\text { 1-2: } 1.38[1.174 ; 1.62] \\
\text { 3-6: } 1.71[1.37 ; 2.14]\end{array}$ & $\begin{array}{l}\text { Multivessel PCI: } 1.48[1.25 ; 1.76] \\
\quad \geq 3 \text { lesions: } 1.72[1.33 ; 2.22] \\
\quad \geq 3 \text { stents: } 1.68[1.40 ; 2.01] \\
\text { Bifurcation with } 2 \text { stents: } 2.33[1.73 ; 3.14] \\
\text { CTO: } 1.00[0.71 ; 1.40] \\
\text { Total stent length } \geq 60 \mathrm{~mm}: 1.47[1.18 ; 1.83]\end{array}$ \\
\hline Cardiac Death & $1.28[1.05 ; 1.55]$ & $\begin{array}{l}\text { 1-2: } 1.22[0.98 ; 1.52] \\
\text { 3-6: } 1.45[1.07 ; 1.97]\end{array}$ & $\begin{array}{c}\text { Multivessel PCI: } 1.39[1.11 ; 1.74] \\
\geq 3 \text { lesions: } 1.17[0.80 ; 1.71] \\
\geq 3 \text { stents: } 1.49[1.17 ; 1.90] \\
\text { Bifurcation with } 2 \text { stents: } 1.34[0.83 ; 2.16] \\
\text { CTO: } 1.09[0.70 ; 1.70] \\
\text { Total stent length } \geq 60 \mathrm{~mm}: 1.33[0.99 ; 1.78]\end{array}$ \\
\hline Target vessel MI & $1.48[1.18 ; 1.86]$ & $\begin{array}{l}\text { 1-2: } 1.31[1.01 ; 1.71] \\
\text { 3-6: } 1.95[1.39 ; 2.74]\end{array}$ & $\begin{array}{c}\text { Multivessel PCI: } 1.52[1.15 ; 1.99] \\
\quad \geq 3 \text { lesions: } 1.50[0.96 ; 2.33] \\
\quad \geq 3 \text { stents: } 1.80[1.36 ; 2.39] \\
\text { Bifurcation with } 2 \text { stents: } 2.53[1.59 ; 4.01]\end{array}$ \\
\hline
\end{tabular}




\begin{tabular}{|c|c|c|c|}
\hline & & & $\begin{array}{l}\text { CTO: } 1.31[0.80 ; 2.15] \\
\text { Total stent length } \geq 60 \mathrm{~mm}: 2.01[1.48 ; 2.74]\end{array}$ \\
\hline CD-TLR & $1.42[1.20 ; 1.68]$ & $\begin{array}{l}\text { 1-2: } 1.34[1.10 ; 1.62] \\
\text { 3-6: } 1.65[1.26 ; 2.15]\end{array}$ & $\begin{array}{l}\text { Multivessel PCI: } 1.38[1.12 ; 1.69] \\
\geq 3 \text { lesions: } 1.59[1.16 ; 2.18] \\
\geq 3 \text { stents: } 1.63[1.31 ; 2.02] \\
\text { Bifurcation with } 2 \text { stents: } 2.31[1.62 ; 3.28] \\
\text { CTO: } 1.07[0.73 ; 1.57] \\
\text { Total stent length } \geq 60 \mathrm{~mm}: 1.58[1.23 ; 2.02]\end{array}$ \\
\hline $\begin{array}{l}\text { Definite/Probable } \\
\text { Stent thrombosis }\end{array}$ & $1.61[1.24 ; 2.10]$ & $\begin{array}{l}\mathbf{1 - 2 :} 1.48[1.10 ; 2.00] \\
\text { 3-6: } 1.98[1.32 ; 2.95]\end{array}$ & $\begin{array}{l}\text { Multivessel PCI: } 1.68[1.24 ; 2.29] \\
\geq 3 \text { lesions: } 1.92[1.20 ; 3.08] \\
\geq 3 \text { stents: } 1.65[1.17 ; 2.33] \\
\text { Bifurcation with } 2 \text { stents: } 2.50[1.44 ; 4.34] \\
\text { CTO: } 2.05 \text { [1.24; } 3.39] \\
\text { Total stent length } \geq 60 \text { mm: } 1.67[1.12 ; 2.48]\end{array}$ \\
\hline
\end{tabular}

*reference is 'No complex' group for each outcome 


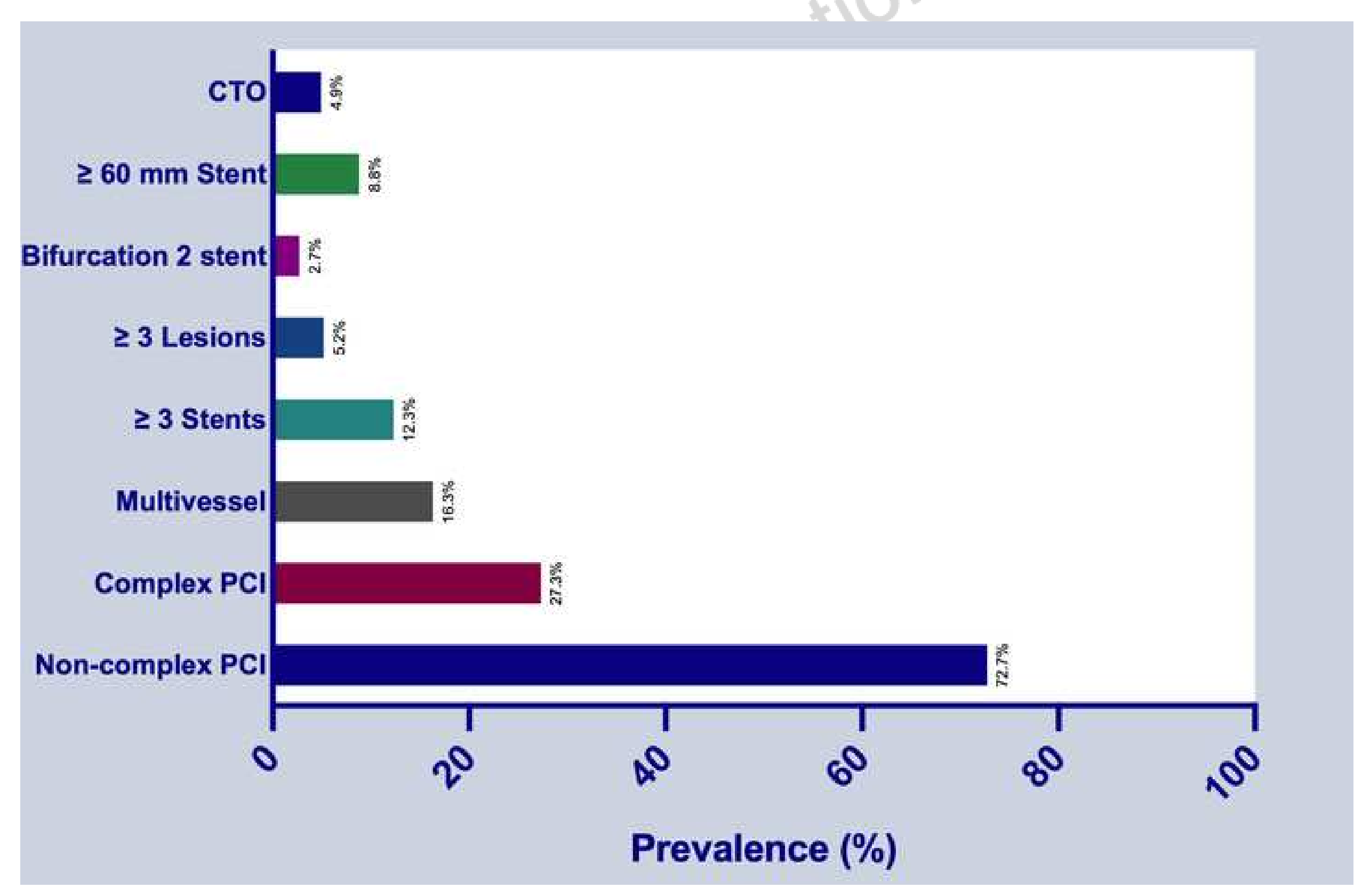




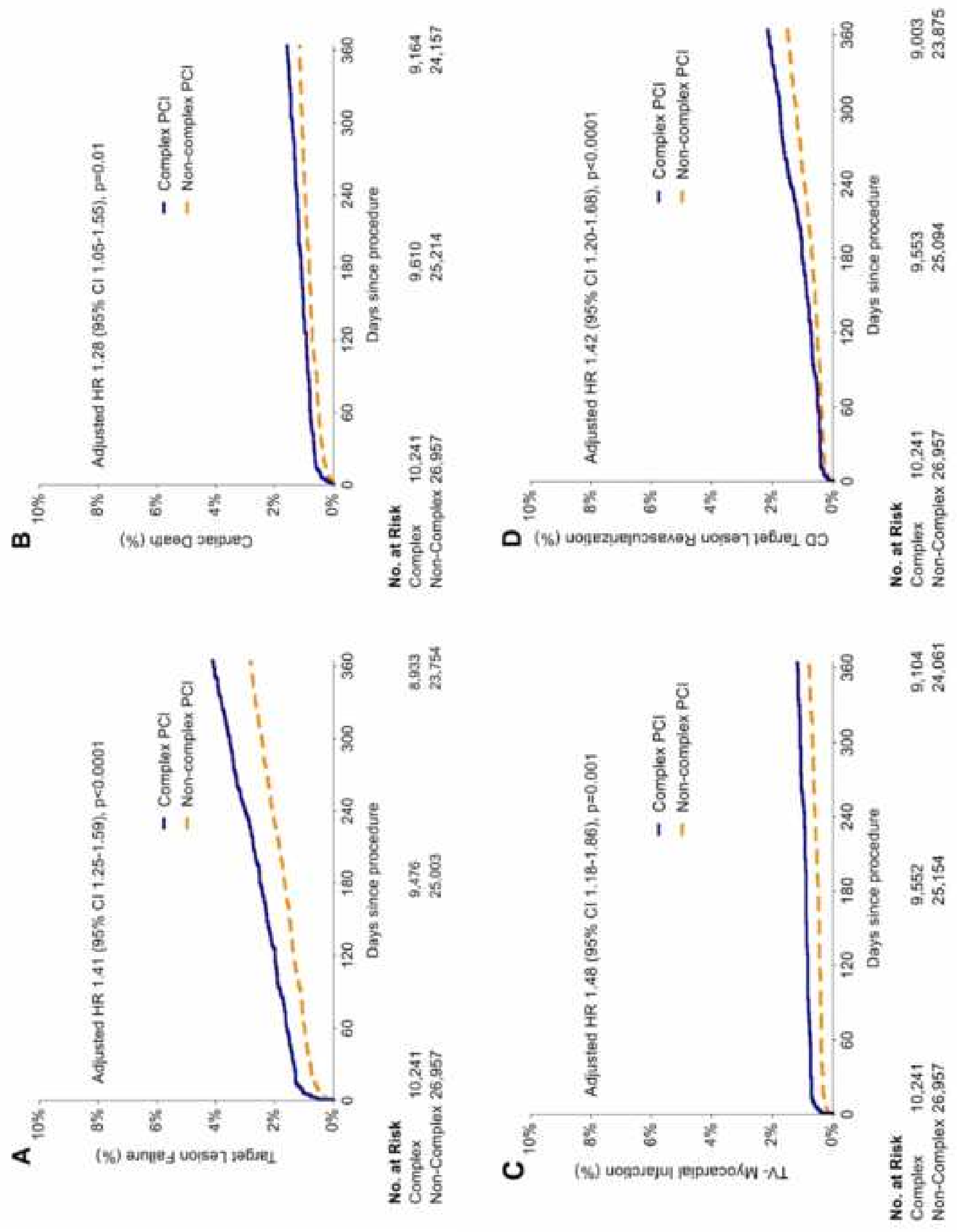




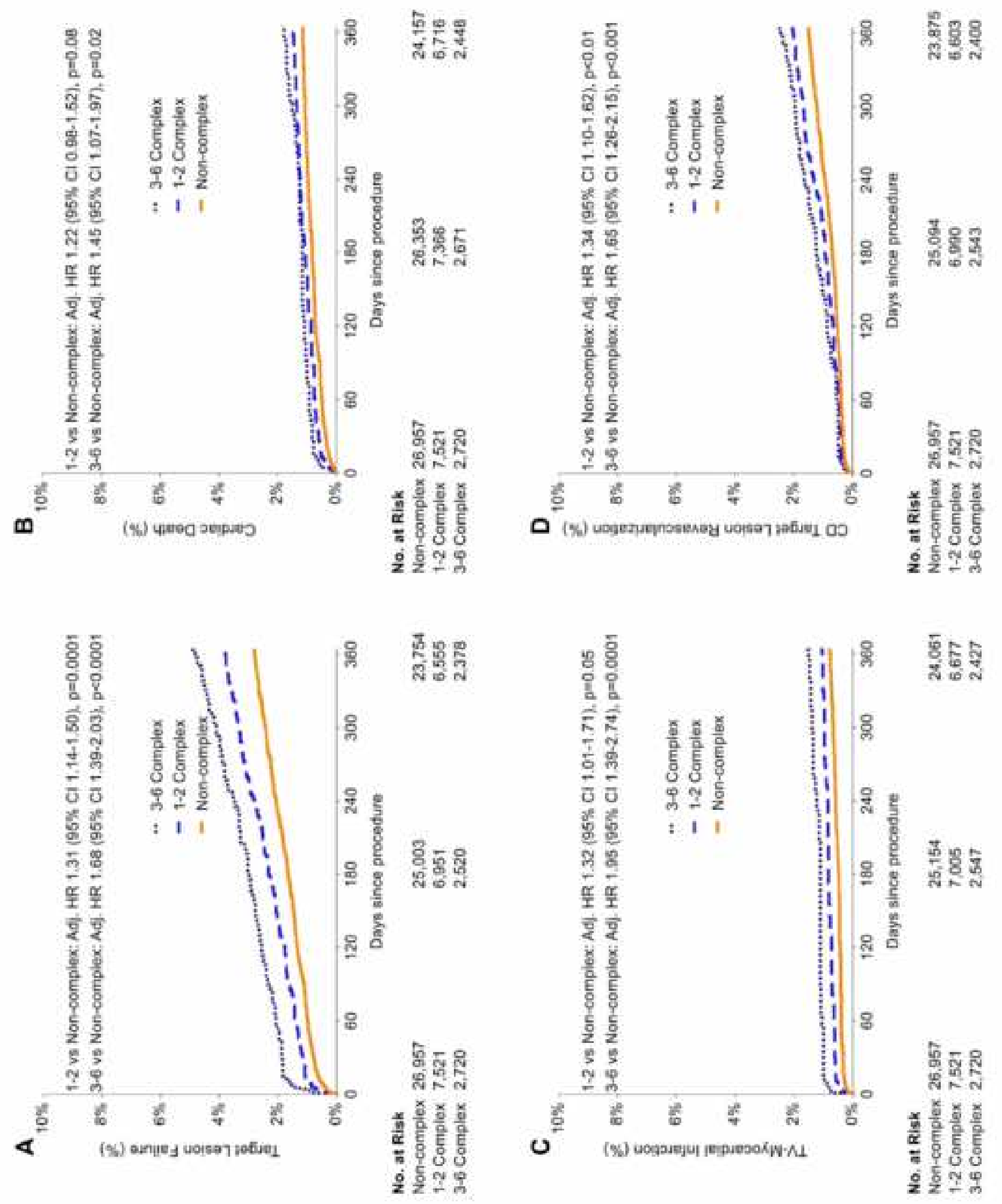



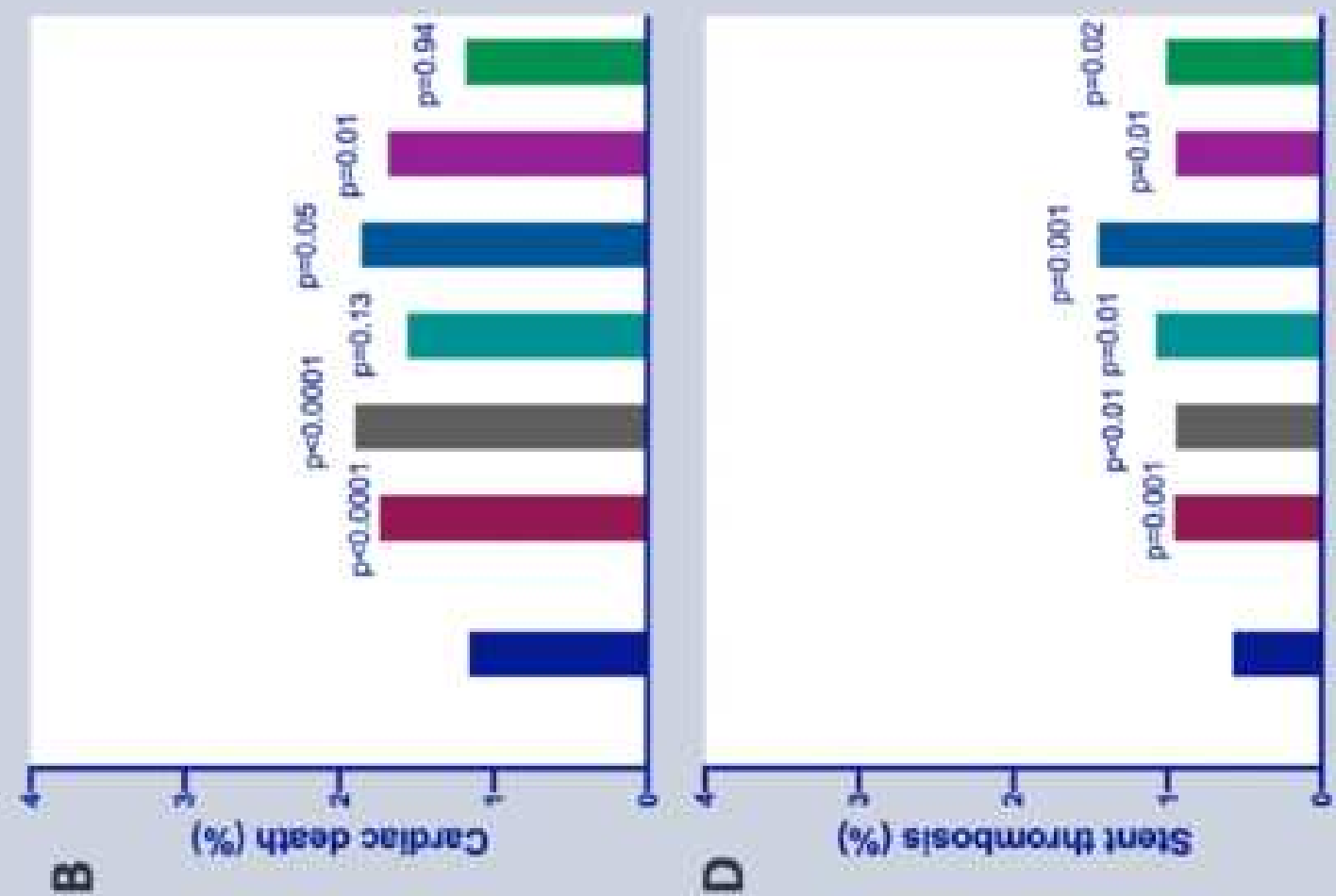

ㅁ

(\%) sisoquouth jueis
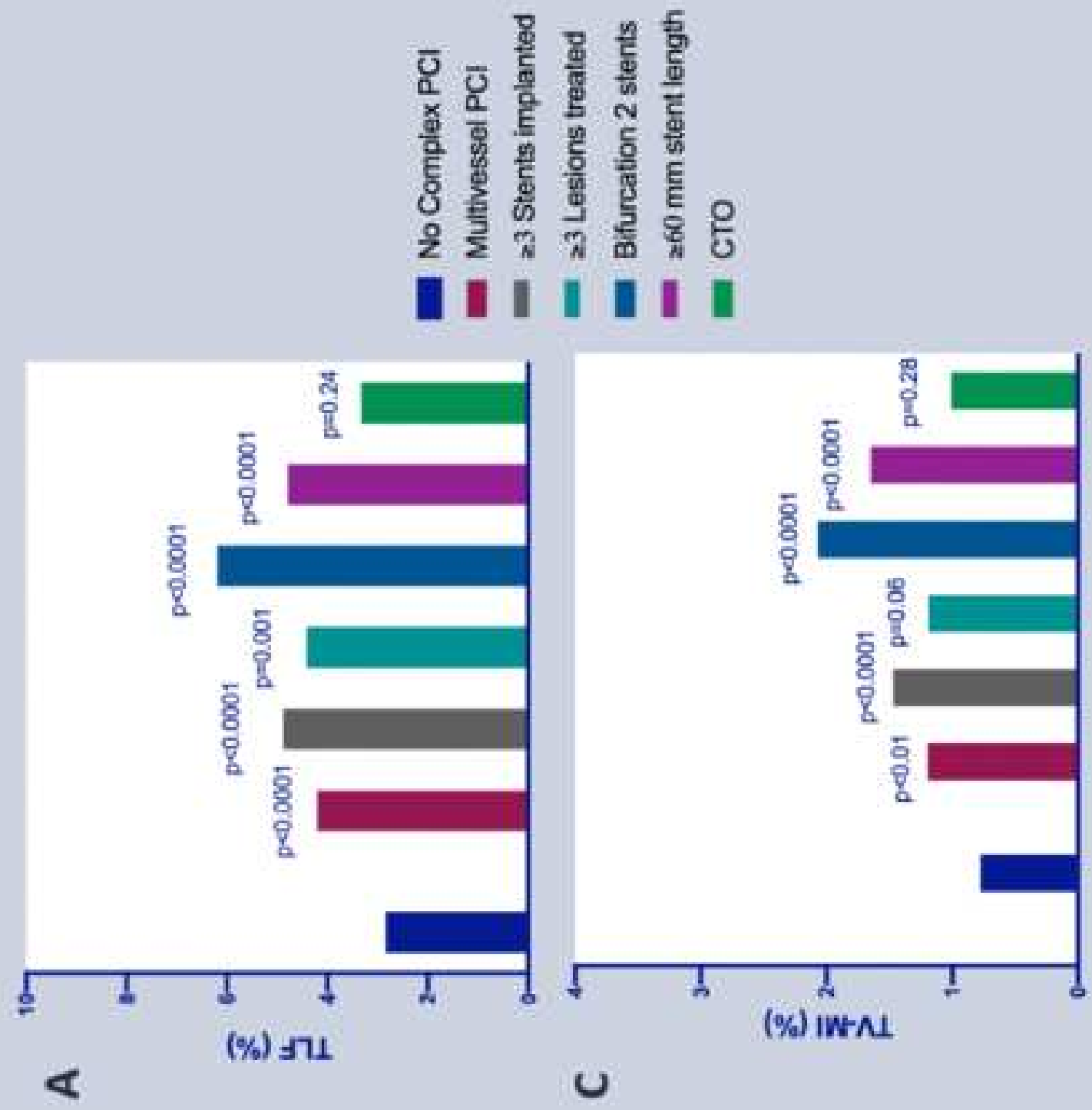

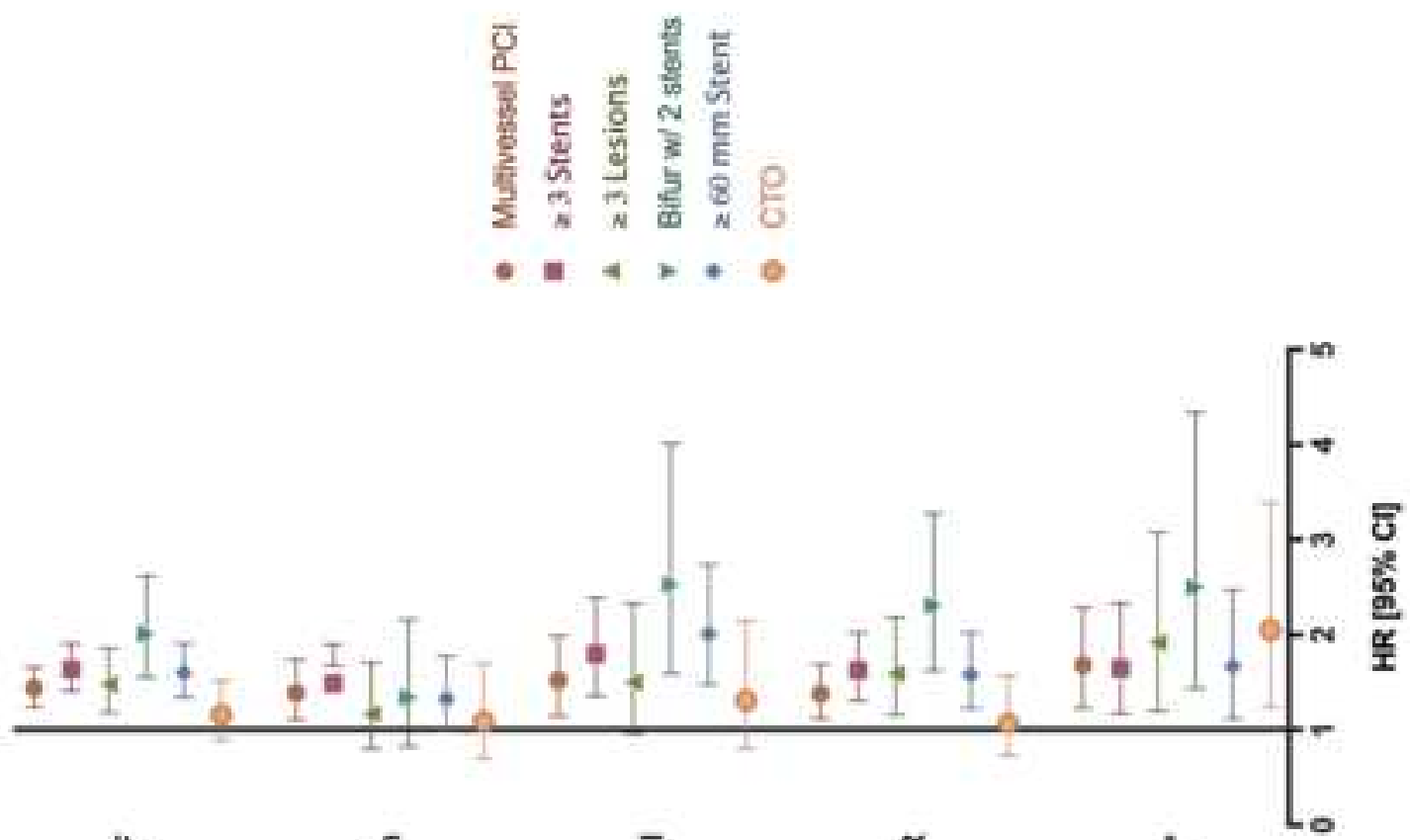
E

$\frac{\frac{f}{2}}{\frac{g}{2}}$

₹

営

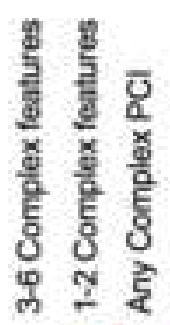

竞

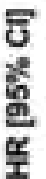

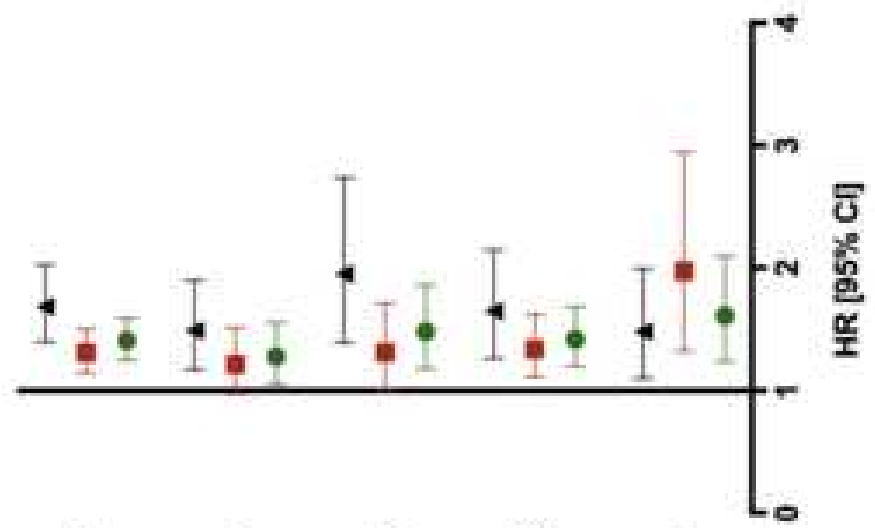

ㄴ.

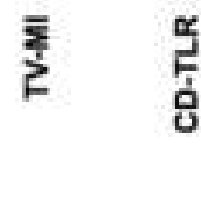


Impact of coronary lesion complexity in percutaneous coronary intervention: 1-year outcomes from the large, multicenter e-ULTIMASTER registry

\section{Supplementary Material}

-Supplementary Figure 1 Flow chart outlining number of patients enrolled and available at 1-year follow-up

-Supplementary Table 1: Baseline clinical characteristics for population divided into three groups according number of complex factors

-Supplementary Table 2: Baseline angiographic and revascularisation procedural characteristics and 1-year pharmacotherapy compliance according to procedure complexity

-Supplementary Table 3: Baseline angiographic and revascularization procedural characteristics for population divided into three groups based upon number of complex factors

- Supplementary Table 4: One-year clinical outcomes according to number of complex factors

-Supplementary Table 5: One-year clinical outcomes for the individual complex PCI features

-Appendix A: Trial registration, study device and follow up.

-Appendix B: List of participating sites and investigators 


\section{Supplementary Figure 1. Flow chart outlining number of patients enrolled and}

available at 1-year follow-up

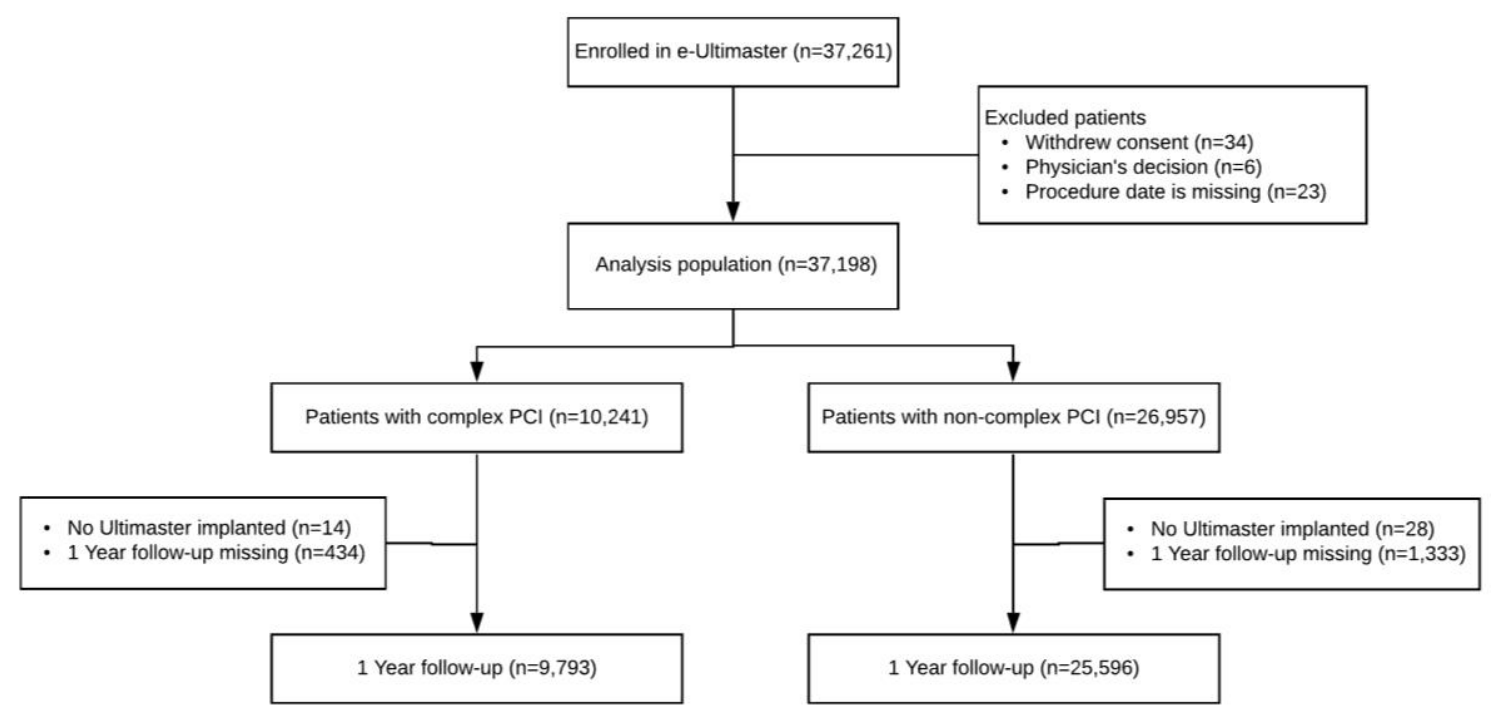

PCI: percutaneous coronary intervention; complex PCI: one or more of the following procedural characteristics: multivessel PCI, $\geq 3$ stents implanted, $\geq 3$ lesions treated, bifurcation PCI with $\geq 2$ stents, total stent length $>60 \mathrm{~mm}$ or chronic total occlusion 
Supplementary Table 1: Baseline clinical characteristics for population divided into three groups according number of complex factors

\begin{tabular}{|l|c|c|c|c|}
\hline $\begin{array}{l}\text { No. of complex risk } \\
\text { factors }\end{array}$ & $\begin{array}{c}\text { None } \\
(\mathrm{N}=26,957)\end{array}$ & $\begin{array}{c}\mathbf{1 - 2} \\
(\mathrm{N}=7,521)\end{array}$ & $\begin{array}{c}\mathbf{3 - 6} \\
(\mathrm{N}=2,720)\end{array}$ & $p$-value \\
\hline Age, years, mean \pm SD & $63.9 \pm 11.3$ & $64.7 \pm 11.1$ & $65.6 \pm 11.0$ & $<0.0001$ \\
\hline Males & $75.1 \%$ & $77.7 \%$ & $80.2 \%$ & $<0.0001$ \\
\hline Diabetes mellitus & $27.0 \%$ & $32.0 \%$ & $32.1 \%$ & $<0.0001$ \\
\hline Hypertension & $66.8 \%$ & $70.2 \%$ & $70.6 \%$ & 0.0006 \\
\hline Hypercholesterolemia & $59.2 \%$ & $61.0 \%$ & $63.6 \%$ & 0.0001 \\
\hline Current smoker & $27.2 \%$ & $24.5 \%$ & $23.1 \%$ & 0.0001 \\
\hline $\begin{array}{l}\text { LVEF [\%], mean } \pm \text { SD } \\
\text { Renal impairment* }\end{array}$ & $54.1 \pm 11.4$ & $53.0 \pm 11.9$ & $52.0 \pm 12.8$ & $<0.0001$ \\
\hline $\begin{array}{l}\text { Previous myocardial } \\
\text { infarction }\end{array}$ & $21.6 \%$ & $8.1 \%$ & $8.3 \%$ & $<0.0001$ \\
\hline $\begin{array}{l}\text { Previous PTCA } \\
\text { Previous CABG }\end{array}$ & $25.2 \%$ & $25.6 \%$ & $27.1 \%$ & $<0.0001$ \\
\hline $\begin{array}{l}\text { Clinical presentation } \\
\text { Syndrome }\end{array}$ & $5.2 \%$ & $6.7 \%$ & $6.6 \%$ & 0.0009 \\
\hline $\begin{array}{l}\text { Acute coronary } \\
\text { syndrome }\end{array}$ & $58.2 \%$ & $48.4 \%$ & $54.1 \%$ & $<0.0001$ \\
\hline
\end{tabular}

$\mathrm{N}$ : number of patients; CABG: coronary artery bypass graft(ing); LVEF: Left ventricular ejection fraction; PTCA: percutaneous transluminal coronary angioplasty; SD: standard deviation; * renal impartment was defined as a glomerular filtration rate of $<60 \mathrm{~mL} / \mathrm{min} / 1.73$ $\mathrm{m}^{2}$ 
Supplementary Table 2. Baseline angiographic and revascularisation procedural characteristics and 1-year pharmacotherapy compliance according to procedure complexity

\begin{tabular}{|c|c|c|c|}
\hline & $\begin{array}{c}\text { Complex PCI } \\
(\mathrm{N}=\mathbf{1 0 , 2 4 1} \\
\mathrm{L}=\mathbf{2 0 , 4 7 8 )}\end{array}$ & $\begin{array}{c}\text { Non-Complex PCI } \\
(\mathrm{N}=\mathbf{2 6 , 9 5 7} \\
\mathbf{L}=\mathbf{2 9 , 2 4 2})\end{array}$ & P-value \\
\hline Radial access & $76.7 \%(7857 / 10241)$ & $84.3 \%(22727 / 26957)$ & $<0.0001$ \\
\hline Multi vessels treated & $59.5 \%(6089 / 10241)$ & $0.0 \%(0 / 26957)$ & $<0.0001$ \\
\hline $\begin{array}{l}\text { Number of lesions treated } \\
\text { at index procedure, mean } \\
\pm \mathrm{SD}\end{array}$ & $1.9 \pm 0.8(10239)$ & $1.1 \pm 0.3(26919)$ & $<0.0001$ \\
\hline \multicolumn{4}{|l|}{$\begin{array}{l}\text { Vessel treated (per } \\
\text { patient) }\end{array}$} \\
\hline Left main & $7.2 \%(735 / 10241)$ & $1.6 \%(423 / 26957)$ & $<0.0001$ \\
\hline Right coronary artery & $47.9 \%(4906 / 10241)$ & $29.2 \%(7859 / 26957)$ & $<0.0001$ \\
\hline $\begin{array}{l}\text { Left anterior } \\
\text { descending }\end{array}$ & $63.5 \%(6501 / 10241)$ & $47.0 \%(12676 / 26957)$ & $<0.0001$ \\
\hline Left circumflex & $45.7 \%(4684 / 10241)$ & $21.0 \%(5659 / 26957)$ & $<0.0001$ \\
\hline $\begin{array}{l}\text { Graft (venous or } \\
\text { arterial) }\end{array}$ & $1.2 \%(126 / 10241)$ & $1.2 \%(318 / 26957)$ & 0.69 \\
\hline \multicolumn{4}{|l|}{$\begin{array}{l}\text { Lesion information (per } \\
\text { patient) }\end{array}$} \\
\hline $\begin{array}{l}\text { In-stent restenotic } \\
\text { lesion }\end{array}$ & $7.5 \%(768 / 10241)$ & $4.5 \%(1206 / 26957)$ & $<0.0001$ \\
\hline Bifurcation & $20.3 \%(2075 / 10241)$ & $8.6 \%(2320 / 26957)$ & $<0.0001$ \\
\hline $\begin{array}{l}\text { Total stent length } \geq 25 \\
\mathrm{~mm}\end{array}$ & $55.1 \%(5646 / 10241)$ & $30.6 \%(8239 / 26957)$ & $<0.0001$ \\
\hline $\begin{array}{l}\text { Any stent diameter } \leq \\
2.75 \mathrm{~mm})\end{array}$ & $60.4 \%(6183 / 10241)$ & $37.3 \%(10058 / 26957)$ & $<0.0001$ \\
\hline $\begin{array}{l}\text { Balloon predilatation (per } \\
\text { lesion) }\end{array}$ & $60.8 \%(12450 / 20478)$ & $57.0 \%(16662 / 29242)$ & $<0.0001$ \\
\hline $\begin{array}{l}\text { Balloon postdilatation (per } \\
\text { lesion) }\end{array}$ & $41.7 \%(8543 / 20478)$ & $39.1 \%(11433 / 29242)$ & $<0.0001$ \\
\hline $\begin{array}{l}\text { B2/C lesion according } \\
\text { AHA/ACC classification } \\
\text { (per lesion) }\end{array}$ & $47.2 \%(9672 / 20478)$ & $39.3 \%(11497 / 29273)$ & $<0.0001$ \\
\hline \multicolumn{4}{|l|}{$\begin{array}{l}\text { Total length of stent } \\
\text { implanted }(\mathrm{mm}), \text { mean } \pm \\
\text { SD }\end{array}$} \\
\hline Per lesion & $30.0 \pm 18.3(16470)$ & $23.3 \pm 9.6(28245)$ & $<0.0001$ \\
\hline Per patient & $48.3 \pm 26.7(10211)$ & $24.5 \pm 10.3(26821)$ & $<0.0001$ \\
\hline \multicolumn{4}{|l|}{ Medication at 1 year } \\
\hline $\begin{array}{l}\text { Dual Antiplatelet } \\
\text { Therapy }\end{array}$ & $70.3 \%(6687 / 9509)$ & $65.8 \%(16469 / 25032)$ & $<0.0001$ \\
\hline Aspirin & $86.5 \%(8221 / 9509)$ & $85.0 \%(21272 / 25032)$ & 0.33 \\
\hline
\end{tabular}




\begin{tabular}{|l|c|c|c|}
\hline P2Y12 Inhibitor & $77.8 \%(7402 / 9509)$ & $73.8 \%(18480 / 25032)$ & $<0.0001$ \\
\hline $\begin{array}{l}\text { Statins and other Lipid } \\
\text { Lowering Drugs }\end{array}$ & $78.8 \%(7497 / 9509)$ & $74.1 \%(18541 / 25032)$ & $<0.0001$ \\
\hline
\end{tabular}

SD: standard deviation; PCI: percutaneous coronary intervention; N: number of patients: L: number of lesions; denominator for medication data is number of patients for whom medication is available 
Supplementary Table 3: Baseline angiographic and revascularization procedural characteristics and 1-year pharmacotherapy compliance based upon number of complex factors

\begin{tabular}{|c|c|c|c|c|}
\hline $\begin{array}{l}\text { No. of complex risk } \\
\text { factors }\end{array}$ & $\begin{array}{c}\text { None } \\
(\mathrm{N}=26,957 \\
\mathrm{L}=29,273)\end{array}$ & $\begin{array}{c}\mathbf{1 - 2} \\
(\mathrm{N}=7,521 \\
\mathrm{L}=12,963)\end{array}$ & $\begin{array}{c}\mathbf{3 - 6} \\
(\mathrm{N}=2,720 \\
\mathrm{L}=7,515)\end{array}$ & $p$-value \\
\hline Radial access & $84.3 \%$ & $77.5 \%$ & $74.7 \%$ & $<0.0001$ \\
\hline Multi vessels treated & $0.0 \%$ & $51.5 \%$ & $81.4 \%$ & $<0.0001$ \\
\hline $\begin{array}{l}\text { Number of lesions } \\
\text { treated }{ }^{*} \text {, mean } \pm \text { SD }\end{array}$ & $1.1 \pm 0.3$ & $1.6 \pm 0.5$ & $2.7 \pm 0.9$ & $<0.0001$ \\
\hline \multicolumn{5}{|l|}{$\begin{array}{l}\text { Vessel treated (per } \\
\text { patient) }\end{array}$} \\
\hline Left Main treated & $1.6 \%$ & $5.6 \%$ & $11.5 \%$ & $<0.0001$ \\
\hline RCA treated & $29.2 \%$ & $43.8 \%$ & $59.2 \%$ & $<0.0001$ \\
\hline LAD treated & $47.0 \%$ & $60.2 \%$ & $72.4 \%$ & $<0.0001$ \\
\hline CX treated & $21.0 \%$ & $41.3 \%$ & $58.1 \%$ & $<0.0001$ \\
\hline Graft & $1.2 \%$ & $1.2 \%$ & $1.3 \%$ & 0.80 \\
\hline \multicolumn{5}{|l|}{$\begin{array}{l}\text { Lesion information } \\
\text { (per patient) }\end{array}$} \\
\hline $\begin{array}{l}\text { In-stent restenotic } \\
\text { lesion }\end{array}$ & $4.5 \%$ & $7.6 \%$ & $7.2 \%$ & $<0.0001$ \\
\hline $\begin{array}{l}\text { Chronic total } \\
\text { occlusion }\end{array}$ & $0.0 \%$ & $18.0 \%$ & $19.6 \%$ & $<0.0001$ \\
\hline Bifurcation & $8.6 \%$ & $18.0 \%$ & $26.4 \%$ & $<0.0001$ \\
\hline $\begin{array}{l}\text { Total stent length } \geq \\
25 \mathrm{~mm}\end{array}$ & $30.6 \%$ & $49.8 \%$ & $69.9 \%$ & $<0.0001$ \\
\hline $\begin{array}{l}\text { Small stent } \leq 2.75 \\
\mathrm{~mm}\end{array}$ & $37.3 \%$ & $56.2 \%$ & $72.0 \%$ & $<0.0001$ \\
\hline $\begin{array}{l}\text { Balloon dilatation } \\
\text { only (per lesion) }\end{array}$ & $1.7 \%$ & $3.5 \%$ & $1.8 \%$ & $<0.0001$ \\
\hline $\begin{array}{l}\text { Predilatation (per } \\
\text { lesion) }\end{array}$ & $57.0 \%$ & $60.9 \%$ & $60.6 \%$ & $<0.0001$ \\
\hline $\begin{array}{l}\text { Postdilatation (per } \\
\text { lesion) }\end{array}$ & $39.1 \%$ & $41.9 \%$ & $41.3 \%$ & $<0.0001$ \\
\hline
\end{tabular}




\begin{tabular}{|c|c|c|c|c|}
\hline $\begin{array}{l}\text { B2/C Lesion (AHA } \\
\text { /ACC classification) } \\
\text { (per lesion) }\end{array}$ & $39.2 \%$ & $59.2 \%$ & $48.3 \%$ & $<0.0001$ \\
\hline $\begin{array}{l}\text { Total length of } \\
\text { successfully implanted } \\
\text { Ultimaster (mm), } \\
\text { mean } \pm \text { SD }\end{array}$ & $24.5 \pm 10.3$ & $47.2 \pm 26.3$ & $67.9 \pm 31.6$ & $<0.0001$ \\
\hline Per patient & $23.3 \pm 9.6$ & $30.7 \pm 19.3$ & $31.4 \pm 20.2$ & $<0.0001$ \\
\hline Per lesion & $65.8 \%$ & $70.0 \%$ & $71.3 \%$ & $<0.0001$ \\
\hline Medication at 1 year & $85.0 \%$ & $86.7 \%$ & $85.7 \%$ & 0.001 \\
\hline $\begin{array}{l}\text { Dual Antiplatelet } \\
\text { Therapy }\end{array}$ & $73.8 \%$ & $77.5 \%$ & $78.9 \%$ & $<0.0001$ \\
\hline Aspirin & $74.1 \%$ & $78.4 \%$ & $80.1 \%$ & $<0.0001$ \\
\hline $\begin{array}{l}\text { P2Y12 Inhibitor } \\
\text { Lipid Lowering } \\
\text { Drugs }\end{array}$ & & & & \\
\hline
\end{tabular}

*including index and staged procedures; SD: standard deviation; PCI: percutaneous coronary intervention; $\mathrm{N}$ : number of patients: L: number of lesions 
Supplementary Table 4. One-year clinical outcomes according to number of complex factors

\begin{tabular}{|c|c|c|c|c|c|}
\hline & $\begin{array}{l}\text { No Complex } \\
\text { PCI features } \\
(\mathrm{N}=25,596)\end{array}$ & $\begin{array}{c}1-2 \\
\text { Complex } \\
\text { PCI } \\
\text { Features } \\
(\mathbf{N}=7,174) \\
\end{array}$ & P-value ${ }^{a}$ & $\begin{array}{c}3-6 \\
\text { Complex } \\
\text { PCI } \\
\text { Features } \\
(\mathbf{N}=2,619) \\
\end{array}$ & P-value ${ }^{b}$ \\
\hline \multicolumn{6}{|l|}{$\begin{array}{l}\text { Composite endpoints, } \\
\%(\mathrm{n})\end{array}$} \\
\hline Target lesion failure & $2.8 \%(727)$ & $3.9 \%(279)$ & $<0.0001$ & $4.9 \%(129)$ & $<0.0001$ \\
\hline Target vessel failure & $3.3 \%(837)$ & $4.5 \%(320)$ & $<0.0001$ & $5.8 \%(151)$ & $<0.0001$ \\
\hline $\begin{array}{l}\text { Patient oriented } \\
\text { composite endpoint }\end{array}$ & $6.0 \%(1532)$ & $7.7 \%(553)$ & $<0.0001$ & $8.4 \%(221)$ & $<0.0001$ \\
\hline \multicolumn{6}{|l|}{ Deaths, \% (n) } \\
\hline Any death & $1.9 \%(490)$ & $2.7 \%(192)$ & $<0.0001$ & $2.4 \%(64)$ & 0.06 \\
\hline Cardiac death & $1.2 \%(298)$ & $1.5 \%(109)$ & 0.02 & $1.8 \%(48)$ & $<0.01$ \\
\hline \multicolumn{6}{|l|}{$\begin{array}{l}\text { Myocardial infarction, } \\
\%(\mathrm{n})^{*}\end{array}$} \\
\hline $\begin{array}{l}\text { Any myocardial } \\
\text { infarction }\end{array}$ & $1.1(272)$ & $1.4 \%(99)$ & 0.02 & $2.0 \%(52)$ & $<0.0001$ \\
\hline $\begin{array}{l}\text { Target vessel } \\
\text { myocardial } \\
\text { infarction }\end{array}$ & $0.8 \%(199)$ & $1.1 \%(76)$ & 0.02 & $1.6 \%(41)$ & $<0.0001$ \\
\hline $\begin{array}{l}\text { Target vessel Q } \\
\text { Wave myocardial } \\
\text { infarction }\end{array}$ & $0.2 \%(52)$ & $0.2 \%(13)$ & 0.71 & $0.3 \%(9)$ & 0.14 \\
\hline $\begin{array}{l}\text { Target vessel non } \mathrm{Q} \\
\text { Wave myocardial } \\
\text { infarction }\end{array}$ & $0.6 \%(147)$ & $0.9 \%(63)$ & $<0.01$ & $1.2 \%(32)$ & $<0.0001$ \\
\hline $\begin{array}{l}\text { Non target vessel } \\
\text { myocardial } \\
\text { infarction }\end{array}$ & $0.3 \%(77)$ & $0.3 \%(24)$ & 0.65 & $0.4 \%(11)$ & 0.30 \\
\hline \multicolumn{6}{|l|}{$\begin{array}{l}\text { Clinically-driven } \\
\text { target lesion } \\
\text { revascularisations, \% } \\
\text { (n) }\end{array}$} \\
\hline All & $1.5 \%(381)$ & $2.0 \%(146)$ & 0.001 & $2.4 \%(64)$ & $<0.001$ \\
\hline PCI & $1.4 \%(350)$ & $1.9 \%(133)$ & $<0.01$ & $2.3 \%(59)$ & $<0.001$ \\
\hline CABG & $0.1 \%(35)$ & $0.2 \%(16)$ & 0.10 & $0.3 \%(7)$ & 0.10 \\
\hline \multicolumn{6}{|l|}{$\begin{array}{l}\text { Clinically-driven } \\
\text { target vessel } \\
\text { revascularisations, \% } \\
\text { (n) }\end{array}$} \\
\hline All & $2.0 \%(515)$ & $2.7 \%(196)$ & $<0.001$ & $3.4 \%(89)$ & $<0.0001$ \\
\hline PCI & $1.8 \%(464)$ & $2.5 \%(176)$ & 0.001 & $3.2 \%(84)$ & $<0.0001$ \\
\hline CABG & $0.2 \%(60)$ & $0.3 \%(24)$ & 0.14 & $0.3 \%(7)$ & 0.74 \\
\hline \multicolumn{6}{|l|}{$\begin{array}{l}\text { Stent thrombosis, \% } \\
\text { (n) }\end{array}$} \\
\hline Definite & $0.4 \%(97)$ & $0.5 \%(35)$ & 0.20 & $0.5 \%(14)$ & 0.23 \\
\hline
\end{tabular}




\begin{tabular}{|l|c|c|c|c|c|}
\hline Probable & $0.2 \%(53)$ & $0.4 \%(26)$ & 0.02 & $0.6 \%(15)$ & $<0.001$ \\
\hline $\begin{array}{l}\text { Definite and } \\
\text { probable }\end{array}$ & $0.6 \%(148)$ & $0.9 \%(61)$ & 0.01 & $1.1 \%(29)$ & 0.001 \\
\hline Bleeding, \% (n) & & & & & \\
\hline Any bleeding & $2.0 \%(511)$ & $2.3 \%(166)$ & 0.09 & $2.5 \%(66)$ & 0.07 \\
\hline BARC 3-5 bleeding & $0.5 \%(126)$ & $0.9 \%(64)$ & $<0.0001$ & $0.5 \%(12)$ & 0.81 \\
\hline
\end{tabular}

*in some cases patients experienced a target vessel as well as a non-target vessel MI at 1-year ( $\mathrm{n}=4$ for non-complex group, $\mathrm{n}=1$ for complex group)

a- comparison between non-complex and 1-2 complex features

b- comparison between non-complex and 3-6 complex features

Target lesion failure: composite of cardiac death, myocardial infarction that could not be clearly attributed to a vessel other than the target vessel and clinically driven target lesion revascularisation. Target vessel failure: composite of cardiac death, target vessel MI and TVR; Patient-oriented composite endpoint: composite of any death, any MI and any coronary revascularisation; BARC: Bleeding academic research consortium 
Supplementary Table 5. One-year clinical outcomes for the individual complex PCI features

\begin{tabular}{|c|c|c|c|c|c|c|c|c|c|c|c|c|c|}
\hline & \multirow[t]{2}{*}{$\begin{array}{c}\text { Non- } \\
\text { complex PCI } \\
(\mathrm{N}=25,596) \\
\end{array}$} & \multicolumn{2}{|c|}{$\begin{array}{c}\text { Multi vessel } \\
\text { PCI } \\
(\mathbf{N = 5 8 5 2 )} \\
\end{array}$} & \multicolumn{2}{|c|}{$\begin{array}{c}\geq 3 \text { stents } \\
\text { implanted } \\
(\mathrm{N}=4424)\end{array}$} & \multicolumn{2}{|c|}{$\begin{array}{c}\geq 3 \text { lesions } \\
\text { treated } \\
(\mathrm{N}=1856)\end{array}$} & \multicolumn{2}{|c|}{$\begin{array}{c}\text { Bifurcation } \\
\text { with } 2 \text { stents } \\
(\mathrm{N}=967)\end{array}$} & \multicolumn{2}{|c|}{$\begin{array}{c}\geq 60 \mathrm{~mm} \text { total } \\
\text { stent length } \\
(\mathrm{N}=3146)\end{array}$} & \multicolumn{2}{|c|}{$\begin{array}{c}\text { Chronic total } \\
\text { occlusion } \\
(\mathrm{N}=1774) \\
\end{array}$} \\
\hline & & & $\begin{array}{c}\mathrm{p}^{-} \\
\text {value }^{1}\end{array}$ & & $\begin{array}{c}\text { p- } \\
\text { value }^{1}\end{array}$ & & $\begin{array}{c}\mathrm{p}^{-} \\
\text {value }^{1}\end{array}$ & & $\begin{array}{c}\mathrm{p}^{-} \\
\text {value }^{1}\end{array}$ & & $\begin{array}{c}\mathrm{p}^{-} \\
\text {value }^{1}\end{array}$ & & $\begin{array}{c}\mathrm{p}- \\
\text { value }^{1}\end{array}$ \\
\hline $\begin{array}{l}\text { Target lesion } \\
\text { failure, } \%(\mathrm{n})\end{array}$ & $2.8 \%(727)$ & $\begin{array}{l}4.2 \% \\
(246) \\
\end{array}$ & $\begin{array}{c}<0.000 \\
1 \\
\end{array}$ & $\begin{array}{l}4.9 \% \\
(216) \\
\end{array}$ & $\begin{array}{c}<0.000 \\
1 \\
\end{array}$ & $\begin{array}{c}4.4 \% \\
(82) \\
\end{array}$ & 0.0001 & $\begin{array}{c}6.2 \% \\
(60) \\
\end{array}$ & $\begin{array}{c}<0.000 \\
1\end{array}$ & $\begin{array}{l}4.8 \% \\
(151) \\
\end{array}$ & $\begin{array}{c}<0.000 \\
1 \\
\end{array}$ & $\begin{array}{c}3.3 \% \\
(59) \\
\end{array}$ & 0.24 \\
\hline $\begin{array}{l}\text { Cardiac death, \% } \\
\text { (n) }\end{array}$ & $1.2 \%(298)$ & $\begin{array}{l}1.7 \% \\
(102) \\
\end{array}$ & $<0.001$ & $\begin{array}{l}1.9 \% \\
(84) \\
\end{array}$ & 0.0001 & $\begin{array}{l}1.6 \% \\
(29) \\
\end{array}$ & 0.13 & $\begin{array}{c}1.9 \% \\
(18) \\
\end{array}$ & 0.05 & $\begin{array}{c}1.7 \% \\
(53) \\
\end{array}$ & 0.01 & $\begin{array}{c}1.2 \% \\
(21)\end{array}$ & 0.94 \\
\hline $\begin{array}{l}\text { Target vessel } \\
\text { myocardial } \\
\text { infarction, \% (n) }\end{array}$ & $0.8 \%$ (199) & $\begin{array}{c}1.2 \% \\
(70)\end{array}$ & $<0.01$ & $\begin{array}{l}1.5 \% \\
(65)\end{array}$ & $\begin{array}{c}<0.000 \\
1\end{array}$ & $\begin{array}{l}1.2 \% \\
(22)\end{array}$ & 0.06 & $\begin{array}{c}2.1 \% \\
(20)\end{array}$ & $\begin{array}{c}<0.000 \\
1\end{array}$ & $\begin{array}{l}1.7 \% \\
(52)\end{array}$ & $\begin{array}{c}<0.000 \\
1\end{array}$ & $\begin{array}{c}1.0 \% \\
(18)\end{array}$ & 0.28 \\
\hline $\begin{array}{l}\text { Clinically-driven } \\
\text { target lesion } \\
\text { revascularisation, } \\
\%(\mathrm{n})\end{array}$ & $1.5 \%(381)$ & $\begin{array}{l}2.1 \% \\
(120)\end{array}$ & $<0.01$ & $\begin{array}{l}2.5 \% \\
(109)\end{array}$ & $\begin{array}{c}<0.000 \\
1\end{array}$ & $\begin{array}{l}2.4 \% \\
(44)\end{array}$ & $<0.01$ & $\begin{array}{c}3.5 \% \\
(34)\end{array}$ & $\begin{array}{c}<0.000 \\
1\end{array}$ & $\begin{array}{c}2.4 \% \\
(76)\end{array}$ & 0.0001 & $\begin{array}{l}1.6 \% \\
(29)\end{array}$ & 0.62 \\
\hline $\begin{array}{l}\text { Stent thrombosis, } \\
\text { definite/ probable, } \\
\% \text { (n) }\end{array}$ & $0.6 \%(148)$ & $\begin{array}{c}1.0 \% \\
(56)\end{array}$ & 0.001 & $\begin{array}{l}1.0 \% \\
(42)\end{array}$ & $<0.01$ & $\begin{array}{l}1.1 \% \\
(20)\end{array}$ & 0.01 & $\begin{array}{c}1.5 \% \\
(14)\end{array}$ & 0.001 & $\begin{array}{c}1.0 \% \\
(30)\end{array}$ & 0.01 & $\begin{array}{c}1.0 \% \\
(18)\end{array}$ & 0.02 \\
\hline
\end{tabular}

p-value: comparison to non-complex PCI for each outcome.

$\mathrm{N}$ : number of patients; Target lesion failure: composite of cardiac death, myocardial infarction that could not be clearly attributed to a vessel other than the target vessel, and clinically driven target lesion revascularisation 


\section{Appendix A: Trial registration, study device and follow up.}

All patients provided written informed consent approved by the Ethics Committee or Institutional Review Board for each participating hospital per the national regulations. In total, 378 hospitals from 50 countries across Europe, Asia, South America (including Mexico) and Africa participated in the registry (full list in Appendix B below). Patient enrolment was between October 2014 and June 2018. Clinical follow-up was after 3 months and after 1 year. For the patient disposition, see flowchart (appendix). The registry was conducted in accordance with the Declaration of Helsinki and country-specific regulatory requirements. The ClinicalTrials.gov study identifier is NCT02188355.

\section{Study device}

The Ultimaster coronary stent system is a new generation, open-cell, cobalt-chromium, thin-strut $(80 \mu \mathrm{m})$ sirolimus-eluting stent with an abluminal biodegradable polymer coating (poly-D,L-lactic acid polycaprolactone). The biodegradable PDLLA/PCL coating is metabolized through dl-lactide and caprolactone into carbon dioxide and water and is expected to fully eliminate over three to four months. Thereafter, only the metallic backbone remains in situ.

\section{Follow up}

Follow-up was either performed by a direct phone contact with the patient or visit of the patient to the outpatient clinic of the hospital. Collection of adverse events was done through a web-based database. At each follow-up, there was a specific question whether any adverse event occurred. If answered positively, all events had to be reported, i.e. death, myocardial infarction, re-PCI, CABG, bleeding, vascular complication, stent thrombosis or other. Further relevant information was collected per event type. 


\section{Appendix A. List of participating sites and investigators}

ARGENTINA: Fundación Favaloro: Oscar Mendiz; Hospital Universitario Austral: Juan Manuel Telayna; Clinica Centro Médico Privado Junin: José Magni; Instituto Cardiovascular de Buenos Aires: Fernando Cura; Sanatorio San Miguel: Juan Lloberas; ARMENIA: Astghik Medical Center (Natali Farm): Mikayel Adamyan; Medical Center Gyumri CJSC: Davit Minasyan; Qancor Cardiovascular MC LLC: Shahen Khachatryan; Republican Medical Center Armenia CJSC: Boghos Sarkissian; Yerevan State Medical University Hospital: Hamayak Sisakian; AUSTRIA: AKH Linz: Clemens Steinwender; Medical University Vienna (AKH): Irene Lang; Medizinische Universität Graz: Gabor Toth-Mayor; BANGLADESH: National Heart Foundation Hospital and Research Institute: Fazila Tun-Nesa Malik; BELARUS: City Clinical Emergency Hospital: Alexander Beimanov; RSPC: Oleg Polonetsky; BELGIUM: AZ Sint Lucas: Jan Nimmegeers; CHR de La Citadelle: Suzanne Pourbaix; Hôpital Ambroise Paré de Mons: Stéphane Carlier; CHU Charleroi: Adel Aminian; CHU UCL Mont Godinne Namur: Antoine Guédès; Epicura Hornu: Philippe Decroly; Imelda Ziekenhuis: Willem De Wilde; Jan Yperman Ziekenhuis: Dries De Cock; OLVZ Aalst: Bernard De Bruyne; UCL Saint Luc: Joelle Kefer; BRAZIL: Eurolatino Natal Pesquisas Medicas (Eurolatino Natal Medical Research): Maria Sanali Paiva; Hospital E Maternidade Dr. Christóvão Da Gama: Bruno Palmieri Bernardi; Hospital Felicio Rocho: Jamil Abdalla Saad; Hospital Moinhos de Vento: Marco Vugman Waistein; Hospital Monte Sinai: Gustavo De Moraes Ramalho; Hospital Santa Cruz: Roberto Otsubo; Hospital São Vicente de Paulo: Rogério Tumelero, Alexandre Tognon; Paraná Medical Research Center: Marcos Franchetti; Unicor: João Eduardo Tinoco De Paula; Unimed Joinville: Bruno Cupertino Migueletto; BULGARIA: Mbal Haskovo: Sevdalin Topalov; Mbal Montana City Clinic Sveti Georgi: Krasimir Pandev; Mbal Sveta Karidad, Plovdiv: Dimitar Karageorgiev; Mbal Sveta Petka Vidin: Diana Trendafilova-Lazaroba; Specialized Cardiology Hospital For Active Treatment: Angel Mitov; Trakiya Hospital, Stara Zagora: Borislov Borisov; Umhat Alexandrovska: Dobrin Vassilev; Umhat St.Ekaterina: Julia Jorgova-Makedonska; CHILE: Clinica Bicentenario: Carlos Romero; Clinica Santa Maria: Pablo Pedreros; Hospital Clínico San Borja Arriaran: Gabriel Maluenda; Hospital Guillermo Grant Benavente: Luis Perez; Hospital Regional de Antofagasta: Bernhard Westerberg; Hospital Regional Puerto Montt: Victor David Assef; Hospital San Juan de Dios: Angel Puentes; COLOMBIA: Centro Cardiovascular de Caldas: Hugo Castaño; Clinica Shaio: Pablo Castro; Fundación Cardiovascular de Colombia (Bucaramanga): Tamara Gorgadze; Instituto del Corazon Bucaramanga: Boris Eduardo Vesga, Hector Hernandez; CZECH REPUBLIC: St Anne's University Hospital Brno: Ladislav Groch; Kardiologie na Bulovce: Miroslav Erbrt; Karlovarská Krajská Nemocnice: Alexandr Schee; FNKV Hospital: Viktor KočKa; Krajska Nemocnice T. Bati: Zdenek Coufal; EGYPT: Al Hayat Hospital: Hany Ragy; Al Nakheel Hospital: Yasser Sadek; Dr Ahmed Abdel Aziz Multicenter: Mohamed 
Abdel Aziz; Dr Hussien Heshmat - As Salam International Hospital: Hussien Heshmat; El Marwa Hospital: Mounir Asman; Italian Hospital: Ihab Daoud; LFouad Cardiac Center: Ahmed Emara; Dr Hisham Ammar Multicenter: Hisham Ammar; Police Hospital: Mohamed Helal; Dr. Tarek Rasid: Tarek Rashid; Um El Korra M Setiha Hospital: Mohamed Setiha; Nile Badrawy Hospital: Sameh Ahmed Salama; Wadi El Neel: Hazem Khamis; ESTONIA: North-Estonia Medical Center: Peep Laanmets; FRANCE: Centre D'exploration-Chirurgie CardioVasculaire: Jean-Louis Leymarie; $\mathrm{CH}$ Bretagne Atlantique: Emmanuelle Filippi; $\mathrm{CH}$ de Marne La Vallée: Simon Elhadad; $\mathrm{CH}$ de Montreuil: Chaib Aures; $\mathrm{CH}$ Haguenau: Fabien De Poli; Groupe Hospitalier de la Rochelle Ré Aunis: Charlotte Trouillet; $\mathrm{CH}$ La Timone Marseille: Jean-Louis Bonnet; $\mathrm{CH}$ Louis Pasteur-Le Coudray: Grégoire Rangé; $\mathrm{CH}$ de Pau: Nicolas Delarche; $\mathrm{CH}$ René Dubos Pontoise: Francois Funck; $\mathrm{CH}$ St Joseph St Luc Lyon: Olivier Dubreuil; $\mathrm{CH}$ Sud Francilien: Pascal Goube; $\mathrm{CH}$ Valence: Stanislas Champin; $\mathrm{CH}$ Yves Le Foll - Saint Brieuc: Denis Amer Zabalawi; CHD Vendée La Roche Sur Yon: Emmanuel Boiffard; CH Général de Saint Quentin: Pierre Henon, Florent Chevalier; CHIC Quimper: Thierry Joseph; CHR Orleans Cardiologie: Olivier Bizeau; CHU Angers: Alain Furber; $\mathrm{CHU}$ Caen: Farzin Beygui; $\mathrm{CHU}$ Clermont-Ferrand: Pascal Motreff; CHU de Poitiers: Sebastien Levesque; Clinique Ambroise Paré: Julien Rosencher; Clinique Diaconat Fonderie Mulhouse: Pradip Kumar Sewoke; Clinique du Millénaire Montpellier: Christophe Piot; Clinique Du Pont de Chaume Montauban: Laurent Delorme; Clinique Louis Pasteur Essey les Nancy: Max Amor; Clinique Rhône Durance: Gilles Bayet; Clinique Saint-Laurent: Yves Biron; Clinique St Hilaire Rouen: Matthieu Godin; Clinique St Joseph: Julien Jeanneteau; GCS Cardiologique de Bayonne: Jean Luc Banos; Groupe Hopitalier Paris Saint Joseph: Romain Cador; Groupement Mutualiste de Grenoble: Jacques Monsegu; Hopital Privé Claude Galien Quincy: Stéphane Champagne; Hopital Albert Schweitzer GHCA Colmar: Plastaras Philoktimon; Hôpital Europøen de Paris la Roseraie: Hakim Benamer; Hopital Privé Dijon Bourgogne: Philippe Brunel; Hopital Privé Jacques Cartier Massy: Thomas Hovasse; Hopital Privé La LouviereLille: Fabrice Leroy; Hopital Privé Saint Martin: Guillaume Lecoq; Hôpital Privé St Martin de Pessac: Levy Raphy; Hôpital Privé St Martin de Pessac: Bernard Karsenty; Institut Arnault Tzanck St Laurent du Var: Alexandre Avran; Le Confluent Nouvelles Cliniques Nantaises: Ashok Tirouvanziam; Nouvel Hopital Civil de Strasbourg: Olivier Morel; Pôle Santé République Clermont Ferrand: Pascal Barraud; Polyclinique Les Fleurs: Philippe Commeau; GEORGIA: Joann Medical Center (JAMC): Lasha Chantladze; HUNGARY Pándy Kálmán Hospital: Jambrik Zoltan; Markusovszky University Teaching Hospital: Lajos Nagy; Moritz Kaposi General Hospital: Andras Vorobcsuk; PECS University: Ivan Horvath; Semmelweis University: Bela Merkely; Szabolcs - Szatmar - Bereg County Hospital and University Teaching Hospital: Kôszegi Zsolt; ICELAND Landspitali National University Hospital of Iceland: Ingibjörg Jóna Guðmundsdóttir; INDIA Dayanand Medical College: Gurpreet Singh Wander; Fortis Hospital: R. Keshava; G. Kuppuswamy Naidu Memorial Hospital: Rajpal Abhaichand; H .J. Doshi Ghatkopar Hindusabha Hospital: Anil Potdar; Heart \& General Hospital: Prakash Chandwani; Kamalnayan Bajaj Hospital, Aurangabad: Ajit Bhagwat; Krishna Institute of Medical Sciences: Rajendra Kumar Premchand; Madras Medical Mission: Ajit Mullasari; Maharaja Agrasen Hospital: B B Chanana; Max Super 
Specialty Hospital: Viveka Kumar; Medanta Hospital: Praveen Chandra; BM Birla Heart Research Cente: Ashwani Mehta; Sree Chitra Tirunal Institute of Medical Sciences \& Technology: Bijulal Sasidharan; Wockhardt Hospital: Prashant Jagtap; INDONESIA Awal Bros Hospital: Bambang Budiono; Binawaluya Cardiac Center: Muhammad Munawar; RSUPN Dr. Cipto Mangunkusumo Hospital: Muhammad Yamin; Dr. Soetomo General Hospital: Yudi Her Oktaviono; Dr. Wahidin Sudirohusodo General Hospital- Awal Bros Hospital: Abdul Hakim Alkatiri; Medistra Hospital: Teguh Santoso; National Cardiovascular Center Harapan Kita Hospital: Doni Firman; Saiful Anwar General Hospital: Sasmojo Widito; IRELAND Cork University Hospital: Eugene McFadden; University Hospital Galway: Jim Crowley; University Hospital Limerick: Thomas Kiernan; ISRAEL Assaf Harofeh Medical Center: Minha Saar; Galilee Medical Center: Marc Brezins; Rambam Medical Center: Ariel Roguin; Ziv Medical Center: Majdi Halabi; JAPAN Gunma Prefectural Cardiovascular Center: Ren Kawaguchi; Higashi Takarazuka Satoh Hospital: Satoru Otsuji; Iwaki Kyoritsu General Hospital: Yoshito Yamamoto; Kakogawa Central City Hospital: Makoto Kadotani; Kansai Rosai Hospital: Takayuki Ishihara; Kokura Memorial Hospital: Kenji Ando; Komaki City Hospital: Katsuhiro Kawaguchi; Kouseikai Takai Hospital: Yasunori Nishida; Mie Heart Center: Hideo Nishikawa; Mimihara General Hospital: Shozo Ishihara; Okamura Memorial Hospital: Yasuhiro Tarutani; Osaka General Medical Center: Takashi Morita; Osaka Rosai Hospital: Masami Nishino; Saiseikai Senri Hospital: Keiji Hirooka; Saiseikai Yamaguchi General Hospital: Shiro Ono; Saiseikai Yokohama City Eastern Hospital: Yoshiaki Ito; Saitama Cardiovascular And Respiratory Center: Makoto Muto; Sakurabashi Watanabe Hospital: Kenshi Fujii; Sapporo Higashi Tokushukai Hospital: Seiji Yamazaki; Seirei Hamamatsu General Hospital: Hisayuki Okada; Seirei Yokohama Hospital: Kazuhiro Ashida; Shonan Kamakura General Hospital: Shigeru Saito; Showa University Fujigaoka Hospital: Hiroshi Suzuki; Tokai University Hachiouji Hospital: Takashi Matsukage; JORDAN Jordan Hospital: Imad Alhaddad; KAZAKHSTAN Aktobe Regional Hospital: Aidos Taumov; Cardiology Center Petropavl: Maxat Kudratullayev; City Hospital \#2: Marat Alikhanov; Clinical Center of Cardiac Surgery and Transplantation: Vadim Seisembekov; Jsc Nat. Scient. Cardiosurgery Ctr.: Marat Aripov; Medical University Clinic West Kazakhstan: Dauren Teleuov; National Surgery Center Almaty: Bauyrzhan Ormanov; Pavlodar Regional Cardiologic Center: Ruslan Baisebenov; Regional Cardiosurgery Center: Azamat Kenzhinovich Zhashkeyev; Rudnyi City Hospital: Azamat Yerzhanov; The Almaty City Heart Center: Orazbek Sakhov; Semey State Medical University, Interventional Cardiology Dpt: Ersin Sabitov; KUWAIT Sabah Al Ahmad Cardiac Center: Vladimir Kotevski; LEBANON Hôpital Abou Jaoudé: Daou Abdo; Labib Medical Center: Ahmad Serhal; LITHUANIA Hospital Of Lithuanian University Of Health Sciences Kauno klinikos: Ramunas Unikas; Klaipeda Seamen's Hospital: Aurimas Knokneris; MACEDONIA City General Hospital: Vladimir Ristovski; University Clinic Of Cardiology: Sasko Kedev; MALAYSIA Desa Park City: Chong Yoon Sin; Hospital Serdang: Abdul Kahar Ghapar; Hospital Sultanah Bahiyah: Abd Syukur Bin Abdullah; Hospital Tengku Ampuan Afzan: Siti Khairani bt Zainal Abidin; HSC Medical Center: Tee Chee Hian; UiTM Sg. Buloh Campus: Nicholas Chua Yul Chye; MEXICO Clinica Hospital San Jose de Navojoa: Santiago Sandoval Navarrete; Hospital Fray Juan de San Miguel de Uruapan: Juan Jorge Beltran Ochoa; Hospital Star Medica 
Merida: Sergio Alonso Villareal Umaña; Casa del Corazon de la Peninsula de Yucatan SCP: Carlos Ramon Rodas Caceres; MOROCCO Cherradi_Clinique Agdal: Rhizlan Cherradi; Clinique Achifaa de Casablanca: Anass Assaidi; Clinique Grant Atlas: Dounia Benzaroual; Clinique Internationale de Marrakech: Fahd Chaara; NETHERLANDS Albert Schweitzer Ziekenhuis: Martijn Scholte; Amphia Ziekenhuis: Alexander J.J. ljsselmuiden; Catharina Ziekenhuis: W.A.L. Pim Tonino; Jeroen Bosch Ziekenhuis: Jawed Polad; Jacob van Eck; Maasstad Ziekenhuis: Pieter Cornelis Smits; Meander MC: Fabrizio Spano; Medisch Centrum Haaglanden: Lucas H. Savalle; Medisch Spectrum Twente, Enschede: Clemens Von Birgelen; Rijnstate Ziekenhuis: Peter W. Danse; Scheper Hospital: Gillian Jessurun; Zorgsaam Ziekenhuis Zeeuws-Vlaanderen: Pieter Bisschops; OMAN Muscat Private Hospital: Amr Hassan; POLAND Insytut Kardiologii im. Prymasa Tys ąclecia Stefana Kardynała Wyszyńskiego: Adam Witkowski; Miedziowe Centrum Zdrowia: Adrian Wlodarczak; Szpital Kliniczny Przemienienia Panskiego Um Im. K. Marcinkowskiego W Poznaniu: Maciej Lesiak; PORTUGAL CHLN Norte Hospital Santa María: Pedro Canas Da Silva; ROMANIA Centrele de Excelenta Ares: Alexandru Voican; Clinicile Icco S.R.L.: Mihai Ursu; Cordismed Timisoara: Milovan Slovenski; Spitalul Judetean de Urgenta Sibiu: Ioan Bitea Cornel; SAUDI ARABIA Dallah Hospital, Riyadh: Samih Lawand; King Fahad Cardiac Center: Tarek Kashour; Prince Abdullah Bin Abdul Aziz Musad Cardiac Center: Muhammad Aurangzaib Mughal; SERBIA Cardiovascular Institute Dedinje: Dragan Sagic; Clinical Center Kragujevac: Nikola Jagic; Cardiology Clinic, Clinical Centre of Serbia: Vladan Vukcevic; Kbc Zvezdara: Alexandar Davidovic; CHC Bezanijska Kosa: Sasa Hinic; SLOVAKIA Stredodlovensky Ustav Srdcovych A Cievnych Chorob: Martin Hudec; SOUTH AFRICA Ethekwini Hospital \& Heart Centre: Shiraz Gafoor; Ismail Soosiwala; Milpark Hospital: Graham Cassel; Netcare Greenacres Hospital: Martin Tawanda Butau; Netcare Union Hospital: Jean-Paul Theron; Netcare Unitas Hospital: Jean Vorster; Netcare Unitas Hospital: Pieter Blomerus; Netcare Unitas Hospital: Iftikar Osman Ebrahim; Netcare Unitas Hospital: Jacobus Badenhorst; SPAIN Bellvitge University Hospital: Joan Antonio Gomez; Complexo Hospitalario Universitario A Coruña (CHUAC): Nicolás Vázquez Gonzalez; Hospital 12 Octubre: Fernando Sarnago; Hospital Cabueñes: Iñigo Lozano; Hospital Clínico Lozano Blesa de Zaragoza: José Ramón Ruiz Arroyo; Hospital Clínico Universitario de Santiago de Compostela: Ramiro Trillo Nouche; Clinico Universitario Valencia: Juan Sanchís; Hospital de Cruces-Barakaldo: Juan Alcibar; Hospital Universitario Donostia: Mariano Larman; Hospital de Galdakao: José Ramón Rumoroso; Hospital de La Cruz Roja de Córdoba: José Suárez de Lezo; Hospital de León: Maria López Benito; Hospital de Mérida: Pablo Cerrato Garcia; Hospital de Navarra: Baltasar Lainez; Hospital del Mar: Beatriz Vaquerizo; Hospital Fundacion Alcorcon: Javier Botas; Hospital G. Trias I Pujol: Eduard Fernández Nofrerias; Hospital General Castellón: Pascual Baello Monge; Hospital General Ciudad Real: Fernando Lozano Ruiz-Poveda; Hospital General de Albacete: Jesus Maria Jimenez Mazuecos; Hospital General Universitario de Burgos: Javier Robles; Hospital Infanta Cristina: José Ramon Lopez Minguez; Hospital Juan Ramón Jiménez: Pepi Garcia; Clinica La Luz: Jorge Palazuelos; Hospital Manises: Gema Miñana; Hospital Marqués de Valdecilla: Jose Javier Zueco; Hospital Meixoeiro-Medtec: Andrés Iñiguez Romo; Hospital Moncloa: Eulogio Garcia 
Fernandez; Hospital Puerta de Hierro: Javier Goicolea; Hospital Reina Sofia de Córdoba: Manuel Pan; Clínica San Fransisco de Asis: Arturo García Touchard; Hospital San Pedro: Javier Fernández; Hospital San Pedro de Alcantara-Caceres: Javier Fernandez Portales; Hospital San Rafael: Gonzalo Peña; Hospital Sant Pau: Antonio Peñaranda Serra; Hospital Santa Lucía de Cartagena Hospital Nostra Señora Rossell: José Domingo Cascón; Hospital Txagorritxu: Alfonso Torres; Hospital Universitario de Gran Canaria Dr Negrin: Pedro Martin Lorenzo; Hospital Universitario de Guadalajara: Javier Balaguer Requena; Hospital Universitario Lucus Augusti (HULA): Raymundo Ocaranza Sanchez; Hospital Universitario Miguel Servet (H.U.M.S.): Jose Antonio Diarte de Miguel; Hospital Vall d'Hebron: Bruno García Del Blanco; Hospital Virgen Arrixaca: Eduardo Pinar; Hospital Virgen de La Salud: P. José Moreu Burgos; Instituto Cardiologico Hospital Campo Grande: Juan Manuel Duran; San Juan de Alicante: Ramón López Palop; Universitario Central de Asturias: César Moris-De La Tassa; SWEDEN Gävle Sjukhus: Robert Kastberg; Mälarsjukshuet: Finn Hjortevang; Skaraborgs Sjukhus v Skövde: Jason Stewart; Sundvalls Sjukhus: Espen Haugen; Universitets Sjukhuset I Örebro: Ole Fröbert; Västmanlads Sjukhus Västerås: Amra Kåregren; SWITZERLAND Cardiocentro Lugano, Ticino: Giovanni Pedrazzini; Herz Gefäss Zentrum Zürich: Peter Wenaweser; Hôpital de La Tour: Edoardo De Benedetti; Hôpitaux Universitaires de Genève: Maro Roffi; Kantonsspital Baselland: Gregor Leibundgut; Kantonsspital Frauenfeld Spital Thurgau AG: Michael Neuhaus; Kantonsspital Luzern: Florim Cuculi; THAILAND Central Chest Institute Of Thailand: Wirash Kehasukcharoen; HRH Princess Maha Chakri Sirindhorn Medical Center (Nakornayok): Arthit Wongsoasup; Paolo Memorial Hospital Phaholyothin: Niphonth Srisuwanunt; TUNISIA Dr. Mohamed Drissa Clinique Hannibal Lac 2: Mohamed Akram Drissa; Dr. Ben Chedli Tarek - Soukra Medical: Ben Chedli Tarek; Dr. Bouziri - Clinique Générale Et Cardiovasculaire de Tunis: Sami Bouziri; Dr. Elyes Kharrat - Bassatine Clinic: Elyes Kharrat; Polyclinique El bassatine_Dr. Mohamed Najeh Abid: Mohamed Najeh Abid; Clinique Générale et Cardiovasculaire de Tunis _Dr. Saloua Trabelsi: Saloua Trabelsi; Polyclinique El Bassatine: Rridha Ennouri; UKRAINE Heart Institute: Andriy Khohlov; NAMS Amosov | Emergency Endovascular Surgery Department: Sergii Salo; NAMS Amosov I X-Ray Diagnostics And Invasive Cardiology Department: Yevhenii Aksonov; S.P.M.C. of Pediatric Cardiology and Cardiac Surgery: Georgiy Mankovskiy; UNITED ARAB EMIRATES Al Noor Hospital Airport: Mohammad Andron; Al Qassimi Hospital: Arif Al Nooryani; Al Zahra Private Hospital, Dubai: Syed Nazir; Belhoul Speciality Hospital, Dubai: Muhammad Adnan Raufi; Dr. Sulaiman Al Habib: Albert Alahmar; Dubai Hospital: Hesham Ahmed Osman; Iranian Hospital, Dubai: Seyed Bagher Tabatabaei; Lifecare Hospital: Khaled Galal; Prime Hospital, Dubai: Murali Krishna; Rashid Hospital: Fahad Omar Baslaib; UNITED KINGDOM Essex Cardiothoracic Centre, Basildon: Rohan Jagathesan; Bedford Hospital: Ramesh de Silva; Blackpool Victoria Hospital: Jonas Eichhofer; Bradford Teaching Hospitals: John Kurian; Croydon University Hospital: Sanjay Kumar; Dorset County Hospital: Javed Iqbal; Eastbourne District General Hospital: David Walker; Freeman Hospital: Rajiv Das; GBS Re Bucks Healthcare NHS Trust (Buckinghamshire, Wycombe): Piers Clifford; James Cook University Hospital: David Austin; Kettering General Hospital: Javed Ehtisham; Kings Mill Hospital: Ifti 
Fazal; Lincoln County Hospital: Kelvin Lee; Lister Hospital, Stevenage: Paul Kotwinski; The Royal Wolverhampton Hospitals: Shahzad Munir; Norfolk And Norwich University Hospital: Alisdair Ryding; Northwick Park Hospital: Ahmed Elghamaz; Plymouth Hospital: Girish Viswanathan; Queen Elizabeth Hospital, Birmingham: Sagar Doshi; Queens Medical Center Nottingham: Sachin Jadhav; Royal Berkshire Hospital: Nicos Spyrou; Royal Blackburn Hospital: John Mcdonald; Royal Bournemouth And Christchurch Hospitals NHS Foundation Trust: Suneel Talwar; Royal Brompton And Harefield: Robert Smith; Royal Cornwall Hospitals: Sen Devadathan; Derby Teaching Hospitals: Kamal Chitkara; The Royal Free Hospital: Sundeep Kalra; Royal Gwent Hospital, Newport: James Cullen; Royal Stoke University Hospital: Mamas Mamas; Royal Sussex Hospital, Brighton: David Hildick Smith; Royal United Hospital, Bath: Kevin Carson; Salisbury District Hospital: Tim Wells; Sandwell And West Birmingham Hospitals: Chetan Varma; Sheffield Teaching Hospital: James Richardson; Tunbridge Wells Hospital: Clive Lawson; UH Coventry and Warwickshire: Rajathurai Thirumaran; University Hospital South Manchester: Hussain Contractor; University Hospital Of Wales: Rito Mitra; University Hospitals Of Leicester: lan Hudson; West Middlesex Hospital: Sukhinder Nijjer; Western Sussex Hospitals - Worthing Hospital: Nicholas Pegge; Worcestershire Acute Hospitals NHS Trust: Helen Routledge; Wrightington Hospital: V J Karthikeyan; UZBEKISTAN Republic Specialized Center of Surgery: Mirjamol Mirumarovich Zufarov; VIETNAM Thong Nhat Hospital: Nguyen Van Tan 